\title{
LOS LIBROS QUE NUNCA FUERON. EL CONTROL DEL CONSEJO DE CASTILLA SOBRE LA IMPRENTA EN EL SIGLO XVIII
}

por

\section{Ceferino Caro López}

I.E.S. «San Isidoro de Sevilla» Madrid

RESUMEN: En el siglo XVIII el Consejo de Castilla ejercía la censura previa de las obras impresas. Sin embargo los censores no fueron nunca exclusivamente laicos y las relaciones con la Inquisición fueron de colaboración estrecha a finales de siglo tras un breve periodo de aparente independencia bacia los años sesenta-setenta. El escrutinio de las peticiones denegadas permite concluir que la censura se ejercía sin criterios establecidos y que las decisiones se dejaban al arbitrio de los censores.

PALABRAS ClAVE: Libros. Censura. Inquisición. Ilustración.

ABSTRACT: In the eighteenth century the Council of Castile practised censorship prior to the printing of books. Yet censors never were exclusively laymen, and the relations with the Inquisition evolved from a short period of apparent independence in the sixties and seventies to open collaboration at the end of the century. The survey of the applications refused allows to draw the conclusions that censorship was practised without any established criteria, and that decisions were left to the censors' arbitrary judgement.

KEY WORDS: Books. Censorship. Inquisition. Enlightenment.

Ante el desolador estado del pensamiento y la ciencia españoles en el Setecientos, parece de obligado cumplimiento acusar inmediatamente a la Inquisición por el papel que jugó en ese oscurantismo cultural, papel que nadie podrá 
negarle ${ }^{1}$; sin embargo convendría recordar que el Santo Tribunal no fue el único organismo encargado de poner trabas a la difusión libre de las ideas en España en el siglo Dieciocho. Parece como si la enorme sombra de esa institución hubiera oscurecido cualquier otro mecanismo de control cultural e hiciera olvidar que una importante función de vigilancia ideológica quedaba reservada para el gobierno mediante la censura previa. Esta consistía en su facultad de conceder o rechazar la licencia de impresión de cualquier obra escrita y era competencia del Consejo de Castilla o de sus magistrados delegados, los Jueces de Imprentas ${ }^{2}$. Es cierto que durante buena parte del Dieciocho la dinámica regalista-ilustrada de los ministerios reformadores tendió a reducir el campo de acción del tribunal religioso, pero fue para ocupar su lugar y no para garantizar mayores márgenes de libertad de pensamiento y expresión. Es evidente que la Ilustración en general, y la española no era una excepción, no luchaba por la tolerancia en cuanto principio abstracto, sino para que se tolerase el acceso al

1 Esta investigación no tiene por objeto el estudio de la Inquisición, sobre la que abundan los estudios. Para los aspectos que aquí se indagan, véase SARRAILH, J.: La España ilustrada de la segunda mitad del siglo XVIII, Madrid 1979, p. 493, donde cita a GAVIRA, Aportaciones para la geografía española del siglo XVIII, Madrid 1932: «El que esto [el estado de la ciencia] observe podrá apreciar qué pétrea muralla fue la Inquisición española para el progreso científico». Sobre la función política de la censura inquisitorial, DEFOURNEAUX, M.: Inquisición y censura de libros en la España del siglo XVIII, Madrid 1963, y STIFFonI, G.: «Intelectuales, sociedad y estado», Historia de España, dir. Jover Zamora, XXIX, II, Madrid 1985, p. 38, nota 69, citando a Kamen: Felipe V realizó solamente la reforma administrativa, no la cultural, y «a causa de esto la Inquisición continuó siendo la guardiana de la sociedad cerrada que no era desafiada por nadie, y los cambios fueron lentos en venir». Stiffoni traza un panorama igualmente pesimista sobre los nuevos aires culturales: «Pero estos aires ¿cómo circulaban en la rarefacta atmósfera de la España del último de los Austrias? ¿Y cuándo y cómo les era posible respirarlos a los intelectuales que vivían en este país donde seguía siendo fortísimo y celoso el control sobre la cultura por parte del Tribunal de la Santa Inquisición? (Ibid. p. 11). El peso de la censura previa y de la inquisitorial también lo considera Enciso uno de los factores por los cuales en España, en la primera mitad del Setecientos, «se imprime poco en España»: «la censura gubernativa e inquisitorial, la competencia de libros [...] los monopolios eclesiásticos, estatales o de ciertas instituciones [...] las tasas impuestas por el Consejo de Castilla y el coste de las licencias». (ENCISO ReCIO, L.M.: «La prensa y la opinión pública», Historia de España, dir. R. Menéndez Pidal, XXXI, tomo I, Madrid 1988, p. 111). Sin embargo la vigilancia censoria laica y religiosa también estaba vigente en la segunda mitad del siglo y la producción editorial aumentó notablemente. La censura previa gubernativa en realidad non influía en la cantidad, sino en la calidad de lo impreso.

2 Los aspectos legales y la colección de medidas emanadas por el Poder durante el Setecientos se han estudiado ya en BRAGADO LORENZO-CARO LÓPEZ, Disposiciones legales sobre censura gubernativa en el siglo XVIII, en curso de publicación. Por esa razón aquí sólo se examinará la práctica política del gobierno con la actividad de censura previa. Sobre la censura de la Ilustración, véanse los pareceres teóricos de Enciso: «Lo que podríamos denominar «teoría» de la censura se basa en un postulado falso: la convicción de que las autoridades públicas tienen facultad para reprimir las ideas contrarias al bien moral o material de la sociedad y potestad de juzgar lo que es «útil» a los ciudadanos». ENCISO RECIO, «Prensa y opinión pública» cit. p. 222. Se refiere a la prensa periódica, pero sus conclusiones se pueden extender a toda la imprenta; sin embargo es difícil compartir su valoración de «Benévola actitud» de la censura hasta los tiempos de Carlos IV (pp. 230-231).

Hispania, LXIII/1, núm. 213 (2003) 161-198 
poder de su ideología, como dice Rosset ${ }^{3}$. La debilidad del sujeto histórico impulsor de las reformas ilustradas en la Península es la que explicaría, por lo tanto, la aparente contradicción de que a partir de la Revolución Francesa la Corona recuperara la alianza con el Santo Oficio para hacer frente común ante la amenaza de novedades políticas y sociales que se iban perfilando, y que gobierno e Inquisición vigilaran y prohibieran la difusión de obras de muy distinto contenido, y no sólo de teología como era habitual para la Inquisición. Este hecho ocurrirá a finales del siglo, pero hasta 1789-1792 la responsabilidad de gran parte de la censura previa recayó en manos de censores laicos. Un estudio de los 633 casos de pareceres negativos emitidos por los censores gubernativos entre 1746 y $1800^{4}$ pone de manifiesto que siempre, incluso en los momentos en que el gobierno retomó la colaboración con el Santo Oficio que se había reducido en un período anterior a causa de la política religiosa de los ilustrados, los censores laicos fueron autores de más denegaciones de licencias de impresión que los religiosos.

TABLA 1.- Censores: serie 1, laicos; serie 2, eclesiásticos.

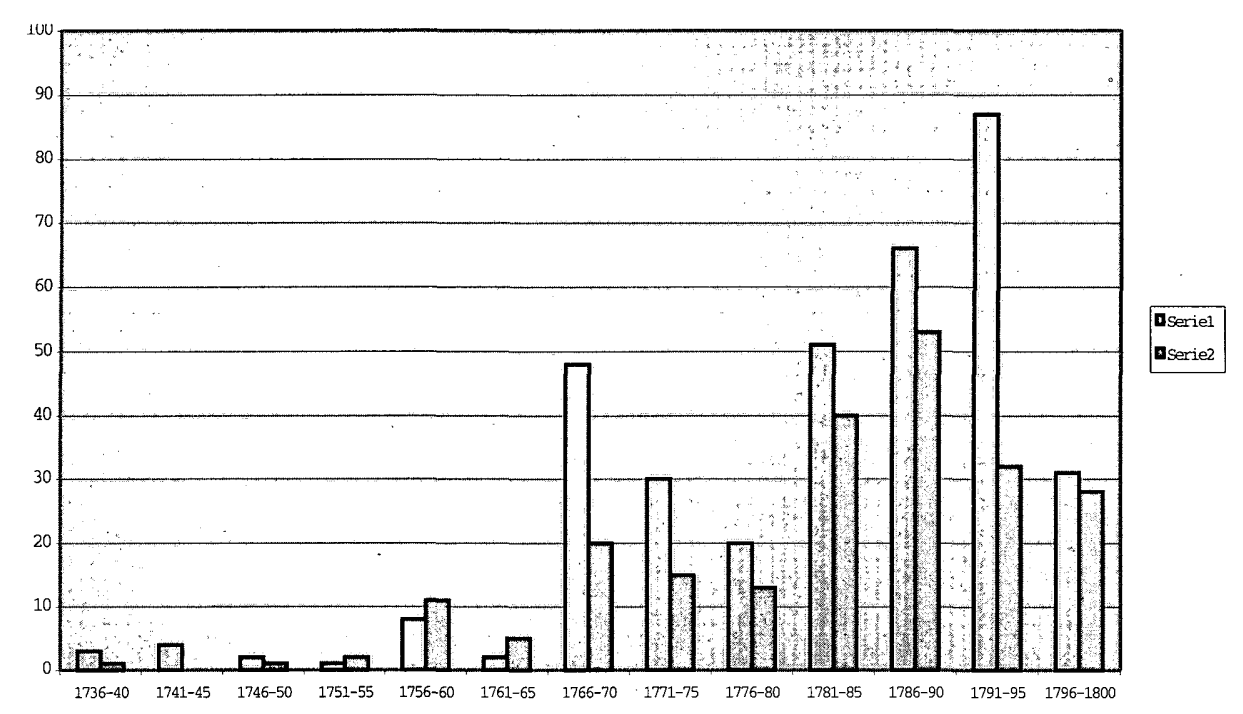

3 MaCho Gómez, P.: «De los inconvenientes de la tolerancia: Clément Rosset y los ilustrados», Censura e Ilustración, Un. Santiago de Compostela 1997. Con los ilustrados nació un nuevo sentido de la noción de tolerancia, distinto del tradicional. El campo de lo tolerado tiene por límite todo lo que contradice su misma afirmación; y sólo se puede ser tolerantes o intolerantes si se lucha a favor o contra algo -pensamiento trágico- (p. 70).

4 La documentación abarca prácticamente todo el siglo, pero las series estadísticas completas sólo se pueden construir a partir de 1745 . Toda la investigación se ha realizado sobre los fondos del Archivo Histórico Nacional, Consejos, series Imprentas y sus agregados e Impresiones (en adelante se citarán como Impresiones, seguidos del número del legajo de cualquiera de las series). 
Por la tabla 1 es dado observar que la tarea de la censura adquirió dimensiones apreciables en los años 1766-1770 seguramente a raíz del Motín de Esquilache como respuesta a la agitación popular. Después, en los diez años siguientes su actividad baja constantemente, para repuntar a partir de 1781. Una dinámica que encuentra dos hechos para explicarla: el malcontento popular primero y la radicalización de las ideas sociales y políticas más tarde. Sin embargo la naturaleza de estas dos situaciones tiene un punto de diferencia muy importante y significativo porque en los años sesenta del Setecientos la proporción de censores laicos fue muy superior a la de los años ochenta. Esto puede querer decir que la coyuntura de mediados de siglo se vio, por parte del Poder, como un asunto de mera política interna, mientras que el escenario de los años ochenta y noventa desbordaba la mera acción política por lo que se involucraban todas las fuerzas dominantes. De hecho en los últimos cinco años del siglo, cuando la Revolución Francesa había desembocado en República, van prácticamente parejos los censores laicos y eclesiásticos. Lo que se ha reducido es el número de negativas, porque bajó considerablemente la cantidad de peticiones presentadas al Consejo. Se puede observar también que, entre los laicos, los censores más activos fueron la Academia Médica de Madrid, con 11 censuras negativas, Estado con 14, el Colegio de Abogados de Madrid con 15, la Real Sociedad Económica con 16, la Real Academia Española que firmó 19, la Real Academia de la Historia con 73 censuras y el Consejo de Castilla con 104. Entre los censores religiosos cabe destacar el Convento de Santo Tomás con 11, el Arzobispo de Toledo con 12, el Oratorio de San Salvador con 21, los Canónigos de San Isidro con 44 y el Vicario General de Madrid con 132. Tal número de censuras negativas emitidas convierte por cierto al Vicario de Madrid en el máximo censor del siglo XVIII, lo que dice muy poco del pretendido laicismo de la política gubernativa de la Ilustración española.

La paradoja de la Ilustración consiste en que era, por una parte, un movimiento ideológico que intentaba fomentar la difusión de la cultura, mientras que por otra parte era la expresión de una clase social que temía que la circulación de las ideas pudiera llevar a la puesta en tela de juicio de los supuestos sociales sobre los que se apoyaba. Entonces para justificar su actuación tenía que encontrar razones que permitieran cercenar la práctica de la especulación intelectual, pero ofreciendo una apariencia de coherencia, como hacía un insospechable Jovellanos. Pues si se admitía que las ciencias, desde mucho tiempo atrás, habían dejado de buscar la verdad y se habían convertido, decía,

en un arbitrio para buscar la vida (...) y a la manera de ciertos insectos que nacen de la podredumbre, y sólo sirven para propagarla, los escolásticos, los pragmáticos, los casuistas y malos profesores de las facultades intelectuales envolvieron en su corrupción de principios, el aprecio y hasta la memoria de las ciencias útiles ${ }^{5}$,

5 JOVEllanos, Informe sobre la Ley Agraria, 1797, citado en SÁNCHEZ RON, M.: Cincel martillo y piedra, Madrid 1999 p. 40 . Para no faltar al sentido histórico más elemental, sin embargo, habrá que recordar con Lucienne Domergue que en el Setecientos los términos Ilustración y censura no

Hispania, LXIII/1, núm. 213 (2003) 161-198 
entonces el censor podía perfectamente prohibir la circulación de un texto o negar la licencia para que se hiciera público.

Fernando Savater ha identificado censura con antiilustración, e Ilustración con voluntad revolucionaria de difundir el saber y la cultura. Así se explicaría el deseo de "cortocircuitar» la transmisión de las ideas por parte de los estamentos sociales más tradicionales. Sin embargo la situación se complicaba enormemente porqué en España, como en otros países, algunos censores estaban infectados por el virus de la Ilustración ${ }^{6}$. Además en el Dieciocho se daba el doble saber «esotérico» reservado a las élites dominantes y el popular, menos atrevido e innovador, por lo que cabe preguntarse por el alcance de la difusión de la cultura, por mucho que a los ojos de los reformadores la necesidad de divulgar ideas y conocimientos fuera incuestionable?

Diferencia evidente entre Inquisición y organismos censorios civiles es que éstos ejercían la censura previa y aquélla actuaba a posteriori. Sin embargo podía ocurrir que una obra impresa con la licencia estatal se denunciara y después prohibiera por la Inquisición. En muchos casos era sólo cuestión de tiempo.

La censura previa gubernativa se ejercía por medio de los magistrados designados por el Consejo de Castilla, aunque había un campo concreto que quedaba fuera de su jurisdicción. Era el de las

eran necesariamente contradictorios pues el concepto de libertad individual en el Dieciocho no incluía desde luego la libertad de expresión. DOMERGUE, L.: «Secularización y censura en tiempos de un monarca ilustrado», Carlos III y la llustración, Madrid 1989, p. 267. Según los casos que cita Maravall, referentes a Federico de Prusia y a Kant, a propósito del tema de si estaba justificado engañar al pueblo, se nota claramente que engaño, libertad de expresión u obstrucción de la difusión del pensamiento se referían exclusivamente a los aspectos intelectuales, no a los asuntos sociopolíticos. «En España es, sin duda, más grave la situación» MARAVALL, J.A.: «Notas sobre la libertad de pensamiento en España durante el siglo de la Ilustración», Estudios de historia del pensamiento español (siglo XVIII), Madrid 1991. Conoce el trabajo de Domergue «desde su lado negativo: la censura» (p. 423). «No aparece ninguna concesión a la libertad de pensamiento» (p. 423) en la política cultural española del Setecientos.

6 SAvater, F.: «Censura en la Europa ilustrada», Censura e llustración, Un. Santiago de Compostela 1997, p. 23.

7 ENCISO RECIO, «Prensa y opinión» cit. pp. 197-198. La Ilustración intentó articular una cultura orientada y según Enciso a ésta «corresponde una prensa censurada» (p. 222). Pero no sólo una prensa; este trabajo deja en claro que también una imprenta. Sobre el clima intelectual de la primera Ilustración, véase Stiffoni, «Intelectuales...» cit. Es muy interesante también LOPEZ, F.: «Ce qu'une Espagne a attendu de la France de la fin du XVIIe siècle à l'époque des lumières», La imagen de Francia en España en la primera mitad del siglo XVIII, Alicante 1996. VIÑAO, A.: "Alfabetización e Ilustración, diez años después», Bulletin Hispanique, 100, 2, 1998. Sobre los libros que realmente se leían, véase en Bulletin Hispanique, 99, 1, 1997, BARrEiro MALlón, B.: «La lectura y sus problemas en el norte de la Península. Estado de la cuestión»; «Les livres espagnols à l'époque moderne»; MOLL, J.: "Libro y sociedad en la España moderna»; Álvarez SANTALÓ, L.C.: "La esquina aritmética de la propiedad del libro en la Sevilla ilustrada»; BUIGUES, J.M. «Las lecturas más comunes de los españoles en el siglo XVIII», Bulletin Hispanique, 100, 2, 1998. 
materias de Estado; tratados de paz y similares; Santo Mysterio de la Inmaculada Concepción; Cosas de las Indias o pertenecientes a otros Tribunales; Comercio, fábricas u otras Maniobras; Pertenecientes a Metales, sus valores y pesos para su comercio; Regalías de la Corona.

Para la censura de estas materias es preciso recordar que mediante el filtro representado por la Secretaría de Estado, especialmente en tiempos de Floridablanca, el rey se reservaba la facultad de controlar las licencias de impresión puenteando la autoridad del Consejo. Por otra parte, las normas que el Juez de Imprentas Curiel había fijado a los censores eran elocuentes porque

se previene a los Censores, que si dichas obras tuviessen conexión con materias de Estado, Tratados de Paces, y sus semejantes

debían indicarlo específicamente al Consejo en el momento de presentar sus calificaciones $^{8}$. Así se rechazaron varias obras, como la de Rustant, Memorias Políticas y Militares. El autor tenía ya las licencias pertinentes, pero Curiel había mandado embargar las pruebas de imprenta porque encontraba en el texto

varios reparos en lo político, y maiores en contener la obra muchas materias de estado que me inabilitaban de dar yo la licencia

como establecía la ley9 ${ }^{9}$ Las censuras en materia de estado las realizaba la Secretaría de Estado, pero las licencias seguía concediéndolas el Consejo: era el caso de la autorización para publicar un Prospecto alusivo a una Academia Literaria en Madrid. El Consejo la concedía

con tal de que se abstenga de escribir y publicar en ellas ninguno de los reales Decretos, causas célebres que versen en los principales Tribunales de la Europa, Leyes que en ellos se publiquen, ni las obras exenciales ni comentarios de la Jurisprudencia, ni menos cosa alguna que trate directa ni indirectamente de los asuntos, y materias del Govierno Nacional y Estrangero.

Lo mismo ocurría con la obra de Somoza y Monsoriu, Reforma de los tribunales, que parecía a los ojos de los censores del Colegio de Abogados de la Corte, «no sólo irreberente a la Magestad y absolutamente odiosa, sino vana y de ningún provecho, cuya lectura para nada importa» mientras recordaban una vez más las

8 GUINARD, P.: La presse espagnole de 1737 à 1791, Paris 1973, p. 26; Instrucción Curiel, 19/VII/1756, AHN Cons leg 11275/23-2.

9 Esto en 1776. Pero el caso seguía abierto a instancias del hijo del autor, y en 1786 era competencia de Campomanes, quien no conseguía recordar dónde había guardado el texto. Los herederos reclamaban con razón, reconocía, pero como había pasado tanto tiempo... AHN Estado leg 3014. También se rechazó la petición de A.R. Ibáñez Llano y Valdés, Discurso sobre las utilidades de la paz, 21/XI/1795, AHN Cons leg 11282/11, con las mismas consideraciones.

Hispania, LXIII/1, núm. 213 (2003) 161-198 
repetidas leyes del Reyno que probiben se impriman las semejantes, especialmente las que tocan al gobierno, $y$ constituciones de estos Reynos ${ }^{10}$.

El mismo José de Cadalso, bajo el pseudónimo de J. Vázquez, tuvo problemas de censura con sus Cartas Marruecas en 4 de octubre de 1774. Primero las censuraba la Española y «parece a la Academia que puede ser útil la Crittica que se hace en ellas de las costumbres antiguas y modernas de los Españoles para corregir varios abusos que en éstas se han introducido» mas el Consejo oponía a este parecer la Real Orden que hablaba en punto de que no se imprimiera nada tocante a los Presidios de África. Cortés, el relator, hacía sin embargo notar «que en estas cartas no se toca asunto alguno de los que comprehende la $\mathrm{R}$. Orden de 18 de febrero último» pero la letra de la ley impedía conceder la licencia solicitada.

En asunto de regalías la vigilancia se organizó más adelantado el siglo, con la Real Provisión de 25 de mayo de 1784 sobre censores en las universidades con lo que se mezclaba la tarea de control ideológico-político con las funciones pedagógicas ${ }^{11}$.

Las razones de la censura, además de religiosas o teológicas también tomaban en consideración conveniencias de orden público. Como decía Suárez, criticando al abate Bonola,

¿Es medio juicioso y oportuno publicar un libelo en forma de fábula capaz de incendiar los espiritus más apagados y modestos, y de ulcerar las más sanas consciencias? ¿Le parece a V.M. que está el mundo civil poco revuelto, que quiere enredar también el mundo religioso con escandalosas revoluciones? 12

Con los libros pensaban los ilustrados vencer «la cruzada de las Luces» que debería avanzar merced a la secularización ${ }^{13}$ pues para ellos el enemigo era el po-

10 Ducreux, 16/X/1789, Impresiones 5555/80; Somoza, rechazada 25/II/1774, Impresiones $5534 / 52$ y también V. Del Seixo, Demostración sobre la decadencia... 1797, AHN Cons leg 11281/83 y del mismo autor Paseo del entendimiento 1799, AHN Cons leg 11283/9. Para la Cartas Marruecas de Cadalso, AHN Consejos leg 5536/7.

11 AHN Cons lib 1526/84.

12 Suárez de Molina, Páxaro en la Liga, 1798, pp. 30-31.

13 Evidente la sobrevaloración de la educación en el pensamiento ilustrado, que da de lado cualquier otro factor influyente en la conducta social, económica o política de los individuos. Educar, por otra parte, consistía en adaptar al individuo a las condiciones sociales dadas (como había teorizado Mandeville). MARAVALL, J.A.: «Idea y función de la educación en el pensamiento ilustrado», Estudios de bistoria del pensamiento español (siglo XVIII), Madrid 1991 pp. 491 ss. y DOMERGUE, «Secularización...» cit. p. 270. Campomanes justificaba al expulsión de los Jesuitas en nombre del peso que habían tenido en las trabas puestas a la circulación de las ideas, especialmente con la prohibición de las obras de Noris, Palafox y el Índice de la Inquisición de 1747 (pp. 271 ss.). No deja de ser paradójico que quien se declaraba paladín de la secularización de la cultura lamentara las trabas a la difusión de obras teológicas, lo que indica llanamente que se trataba de argumentaciones de pura polémica. 
der clerical, y por eso la represión de los escritos se acentuó tras el Motín de Esquilache. Domergue ha llamado a la censura literaria «autre branche de police» ${ }^{14}$.

A principios del Dieciocho el iter administrativo para solicitar la licencia de impresión era bastante sencillo: en el mismo papel sellado en que el autor había presentado su petición se apuntaba a quién se remitía el texto para que lo calificara; a su vez el censor escribía su parecer, siempre muy breve, en el mismo papel y a continuación se indicaba la resolución del Juez de Imprentas que era el magistrado encargado de pronunciar la sentencia. Lo mismo se hacía para la tasa. En sus primeros momentos la petición de licencia se dirigía al escribano de Cámara, por ejemplo a Munilla, entre 1737 y 1738, y éste distribuía los expedientes entre los consejeros, una vez sabido el parecer de los censores.

Como era de esperar esa práctica cambió mucho en el curso del tiempo. En la segunda mitad del siglo, generalmente, para impresiones de obras de carácter religioso, se buscaban censores eclesiásticos, y su censura razonada era la base de las decisiones del Consejo ${ }^{15}$. Por norma, también, los textos de carácter teórico en materias profanas o de literatura se encomendaban en cambio a organismos laicos, especialmente las Reales Academias, aunque como se verá más abajo ésta costumbre nunca fue una práctica sin excepciones.

Durante la primera parte del siglo XVIII las denegaciones de licencia de impresión fueron prácticamente inexistentes $\multimap$ así al menos aparece en los registros de los años Treinta, Cuarenta y Cincuenta- mientras que en el último tercio del siglo hay abundantes decisiones negativas ${ }^{16}$.

El gráfico demuestra claramente que la eficacia negativa de la censura es un hecho de la segunda mitad del siglo, precisamente del período de la Ilustración plena y que sus dos picos corresponden a dos coyunturas políticas muy bien definidas, esto es, la primera, a los años de mayor dureza gubernamental ante las órdenes religiosas. Son los años del Motín de Esquilache, de la expulsión de los jesuitas y de la primera desamortización de bienes de los regulares, entre 1766 y 1773 . El segundo pico representa los efectos sobre la libertad de pensamiento de las noticias de la Revolución Francesa. El número de licencias de-

14 «Notons la date à laquelle les sphères dirigeantes se penchent sur le problème: à la fín des années 1760 , donc en plein prurit réformateur, mais aussi au terme d'une décennie qui s'est vue profondément marquée par le motín de Esquilache (1766), avec pour conséquence la reprise en mains systématique des esprits, les temps forts de cette répression ayante été l'expulsión des jésuites, la mise au pas de l'Inquisition, le lancement de la réforme universitaire». DOMERGUE, L. La censure des livres en Espagne à la fin de l'Ancien Régime, Madrid 1996 p. 51.

15 Impresiones 5542.

16 En AHN, Impresiones 50660 a 50662, es decir para el período de 1764 a 1768, sólo se dan tres casos de rechazo de licencia y una prohibición de libro ya impreso. Lucienne Domergue ha llevado a cabo una estadística según la cual entre 1768 y 1805 con lagunas en 1769-1770, se cuen$\tan 2.925$ licencias y 509 rechazos. Pero la historiadora no ha visto la serie completa, e incluso los sondeos que ella misma hace dan una imagen bastante más severa aún de la actitud de la censura. DOMERGUe, La censure. . . cit. pp. 337-338.

Hispania, LXIII/1, núm. 213 (2003) 161-198 
negadas se dispara a partir de 1790 y es máximo en los años en torno a la proclamación de la república y la decapitación de Luis XVI.

TABLA 2.

Licencias de impresión denegadas, $1724-1800$

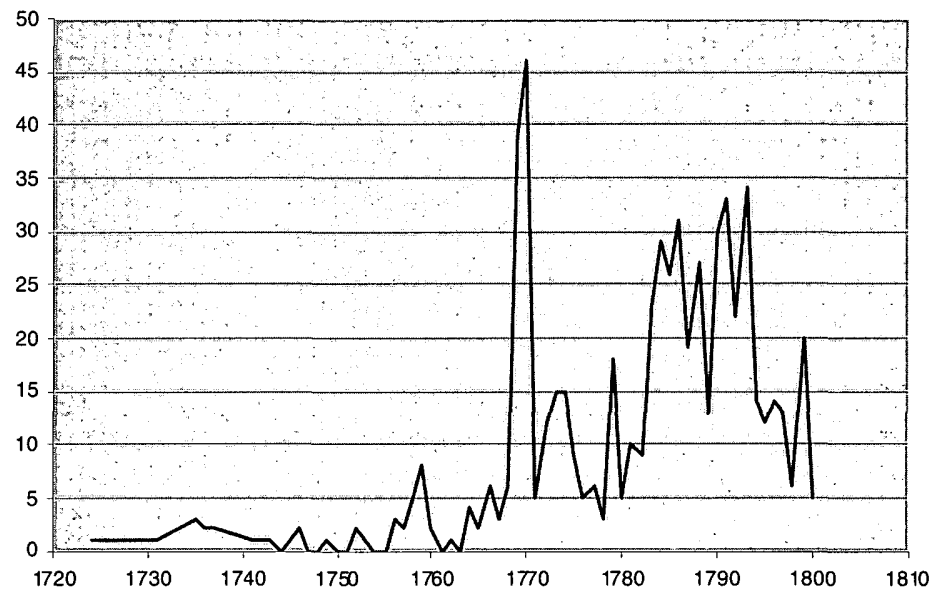

Ahora bien, como se hace difícil aceptar la posibilidad de que la calidad literaria de los textos censurados se hubiera reducido tan drásticamente en tan poco tiempo, habrá que entender que lo que cambió con el siglo fue el filtro usado para valorar las obras que se quería imprimir, haciéndolo más severo y adaptándolo a los intereses prácticos del gobierno en cada contingencia. No debe dejar de llamar la atención el hecho de que los censores de la primera mitad del siglo eran casi en su totalidad eclesiásticos pero, a pesar de lo que se pudiera esperar, se mostraban bastante más benévolos que sus homólogos sucesivos, a menudo laicos. Aunque se debe tener presente la antigua práctica de que el autor podía elegir censor para su obra, habrá que reconocer que el factor que explica la rigidez de la censura en los últimos años del Setecientos es, más que la personalidad de los censores, la intención política - explícita o no- de la censura gubernativa.

La serie Privilegios, Licencias y Tasas de Libros, del Patronato de Castilla indica otra manera de llevar los expedientes burocráticos ya en la segunda mitad del siglo:

remítase esta obra a Censura de la Rl. Academia de la Historia y con el Informe que biciere que se remita derechamente al Consejo por mano de el presente secretario escribano de Cámara y de Gobierno se traiga, 
decía el secretario Igareda para la censura de la Genealogía analítica de los Antiguos Régulos de Galicia de Bernardo de Cerbella ${ }^{17}$. En su conjunto, los expedientes de este organismo son más ágiles en su tramitación, en la doble vertiente de licencias de reimpresión - que estando a los documentos, siempre se concedían-y de primera impresión. A éstas últimas se les pierde la pista tal vez porque formen parte de la serie Impresiones del Consejo de Castilla.

Más tarde, en 1789, se formularon otras reglas para presentar la petición de licencia al Juez Subdelegado según mandaba el Consejo de Castilla. Primero, la petición debía ir siempre firmada; segundo, se debía presentar ante el censor designado por el Juez de Imprentas; tercero, «no se pongan expresiones torpes ni lúbricas, ni tampoco sátiras de ninguna especie»; cuarto, en el caso de traducciones, se debía indicar el autor del original; quinto, una vez impresa la obra se debía presentar un ejemplar al Juez de Imprentas para cotejarlo con el original autorizado y, sexto,

finalmente, los Censores no permitirán que en libros ni papeles se trate de asuntos resueltos por S.M. o sus Ministros y tribunales sin consulta o permiso de S.M. o de los mismos Tribunales y ministros respectivos, ni tampoco de los que están pendientes formalmente: pues de lo contrario serán responsables el Autor, $y$ Censores $^{18}$.

Si se observan los legajos relativos a los primeros años Noventa, sorprendentemente se notará la ausencia de títulos referentes a la actualidad política de Europa y a los grandes acontecimientos que estaban ocurriendo en Francia. Por estos ejèmplos es por lo que se puede decir, por una parte, que el cordón sanitario aplicado para cerrar las fronteras fue más eficaz de lo que se pudiera creer, pero también, por otra, que en España los escritores habían interiorizado la prohibición de manifestar sus ideas hasta el punto de aplicarse una autocensura cultural que llevaba a cultivar las musas más inocentes y tradicionales, como siempre ocurre en momentos de falta de libertad de expresión ${ }^{19}$.

De las disposiciones censorias se puede notar que los ministros ilustrados no estaban dispuestos a encajar críticas a sus actuaciones de gobierno, como se refleja en el ordenamiento legal. Los primeros en respetar al gobierno debían ser los religiosos, que no debían murmurar contra los ministros, porque su ejemplo se contagiaría a todos los vasallos de una nación tan católica como la española:

17 8/II/1769, Impresiones 50663. B. De Cerbella, Genealogía analítica de los Antiguos Régulos de Galicia.

18 Reglas que deberán observar...1789 Impresiones 5556/2.

19 Véanse en AHN, Consejos, los legajos 5556, 5557, 5558 y siguientes de la serie Impresiones. La autocensura prudente se desvela en el caso de L. Hervás y Panduro, Idea del Universo, 1787, o cuanto menos la actitud del autor ante su obra hace pensarlo; el 30 de octubre de 1787 pedía al Consejo que se le devolviera el manuscrito para corregir "varios errores con que se halla y repararía el Censor» antes de que se emitiera el informe de la censura. Impresiones 5553/6. 
El amor, y el respeto a los Soberanos a la Familia Real y al Gobierno es una obligación, que dictan las leyes fundamentales del Estado, y enseñan las Letras Divinas a los Súbditos

y los religiosos que incurrieran en ese grave delito podrían ser tratados como reos de traición según la Nueva Recopilación, VIII, IV, 11, lo que no era, por otra parte, más que el recuerdo de una ley de Juan I en Segovia, recogida debidamente en la misma Recopilación. En este caso concreto, los censores se volvían censurados y las jerarquías eclesiásticas recibían el encargo de velar por la buena conducta de sus súbditos ${ }^{20}$.

Así que se deberá tener siempre en mientes que la censura literaria servía a los intereses políticos por mucho que se revistiera de justificaciones pseudoculturales, como se verá más abajo. En 1786 se daba una Orden inspirada por la Sala de Alcaldes de Madrid a propósito del abuso de sátiras contra los ministros de justicia, con la que se proponía

no consentir expresión alguna ofensiva a los subalternos de Justicia que los ponga en ridículo, ni que se permita salgan los cómicos al Teatro con golilla y varas probiviendo tales representaciones injuriosas, pues para representar un Alguacil podrán hacerlo en trage de militar y vestido negro acaso con mayor propiedad

firmada por Campomanes ${ }^{21}$. En este caso concreto se podría decir que las dos facetas, de la censura política y la literaria, se unen en cierta medida pues se trataba de intervenir en el ámbito del teatro y por cierto no dejará de llamar la atención la minuciosidad reglamentista del pensamiento ilustrado que intervenía incluso para dar indicaciones de dirección escénica. En un orden de cosas más amplio, a partir de los años ochenta del Setecientos, se empieza a tomar conciencia de la importancia de los diarios en cuanto medio de difusión del pensamiento, en cuestiones bastante más importantes que las frivolidades de unos cómicos ${ }^{22}$. Los protagonistas de la vigilancia son siempre los mismos, y no precisamente dos miembros del Santo Oficio: Floridablanca y Campomanes, con la comunicación del primero al segundo:

20 AHN Cons lib 1483/54.

21 Orden firmada en 3/VII/1786, remitida a los Alcaldes en 30/VII/1786 y después en 9/VIII/1786. AHN Cons lib 1376 ff. 1382 r-v.

22 Por la vía reservada se mandaba investigar si hubiera «una mano oculta nacional o estrangera» en el caso del Discurso 31 escrito por Cañuelo y Heredia. Casimiro Flores Canseco lo había censurado sin encontrar inconveniencias, y ahora el pobre autor preguntaba si había cometido alguna falta. El Censor, 10/IX/1781, AHN Cons leg 11929/1. Cañuelo fue por cierto un defensor de la visión más progresista de la Ilustración: Álvarez JunCO, J.: Mater dolorosa, Madrid 2001 p. 174, nota 106. Nótese por cierto que Cañuelo dirigía un periódico generosamente financiado por el gobierno, GÓMEZ-REINO Y CARNOTA, E.: Aproximación histórica al derecho de la imprenta y de la prensa en España (1480-1966), Madrid 1977, p. 47.

Hispania, LXIII/1, núm. 213 (2003) 161-198 
Ha notado S.M. se imprimen otros [papeles] contra la letra y el espíritu de las órdenes comunicadas en la materia, y señaladamente en el llamado Espiritu de los mejores diarios, pues se publican allí cartas que tratan de la autoridad del soberano, de la injusticia de los tributos, y reglas dadas al comercio por el govierno, $y$ de otras ideas fundadas en una theoría seductora y falsa como que se toma de bechos inciertos, o mal averiguados, o principios equivocados, de los quales han nacido muchos y graves males en otros Reinos

en una carta de 23 de marzo de 1789. El ministro pedía que el Consejo hiciera respetar las leyes vigentes

o se verá precisado a tomar providencias más serias contra los Autores, y Censores, y otros Subalternos negligentes en obedecer lo mandado

es decir, que acusaba directamente al Consejo de Castilla de no cumplir con sus cometidos en asuntos de control de impresos, mientras que la amenaza de tomar medidas contra los subalternos significaba efectivamente que el Consejo no lo hacía ${ }^{23}$. Se puede notar la fecha premonitoria de esta comunicación, muy poco antes de que la Revolución Francesa llegara para añadir más preocupaciones a los censores, tanto es así que bajo Carlos IV los elementos de control y sobre todo de represión de los papeles clandestinos se enriquecieron con la presencia de la Superintendencia de Policía. Con la necesidad de defender el orden social, se empezaría a controlar severamente también la importación de libros extranjeros, ahora no ya para favorecer a la industria nacional, como en tiempos de Carlos III, sino para impedir la difusión de las ideas revolucionarias, con la Real Orden de 15 de octubre de $1792^{24}$, mientras que en asuntos de política cultural interna se volvería a recurrir a la experiencia de la Inquisición. Recién acabado el siglo ya se tiene una prueba tangible de la entrega del Trono a su mejor defensor:

Aunque por el artículo 2 de la Real Cédula de 16 de Junio de 1768 se previno al Tribunal de la Inquisición que no impidiera el curso de los libros, obras o papeles a título interin se califican, quiere el rey conformándose con lo expuesto por V.E. [...] proibir la Institución Cristiana [...]. Y como S.M. está bien satisfecho del celo, y circunspección con que procede este Tribunal, es su real voluntad que sin embargo del artículo citado proceda del mismo modo en quantas obra tenga fundado motibo para creer que en todo o en parte llegará el caso de probibirse su lectura [...]. Queda este Tribunal expedito para proceder a prevenir con tiempo los daños que de otro modo pudieran ser irremediables en muchos casos ${ }^{25}$.

23 Impresiones $5555 / 82$

21 Orteu Berrocal, M.: «La literatura clandestina en la España de Carlos IV", Cuadernos de Historia Moderna, 17, 1996 pp. 76 ss.

25 Se trata de la Institución Cristiana o explicación de la Doctrina Cristiana, traducida del francés por Fray Pedro Joseph Gallareta O.S.A. RO 28/1/1801, Impresiones 50691. El dictado de la Real Orden sanciona la quiebra de los intentos de laicización de la cultura tímidamente emprendidos por la Ilustración española.

Hispania, LXIII/1, núm. 213 (2003) 161-198 
Tras haber esbozado someramente el marco genérico de la política censoria, se puede intentar construir una contestación congruente a la pregunta ipor qué se rechazaba una licencia de impresión? Por falta de doctrina en el texto examinado, puede ser una respuesta oportuna. Eso ocurría con obras que seguramente estaban animadas por las mejores intenciones, pero que

está[ban] llena[s] de proposiciones erróneas o muy oscuras susceptibles de mal sentido [...]. Despreciable[s] porque no procede el Autor por principios, ni propone las nociones que son del caso

come le ocurría a Arnero, quien había intentado escribir para rebatir las ideas de Rousseau acerca de la infelicidad del hombre ${ }^{26}$.

Por las mismas faltas de doctrina se rechazaban Las cinco bienaventuranzas de Fray Juan de Ávila, no sólo porque eran un plagio de Gerson, sino porque estaban editadas en modo defectuoso ${ }^{27}$. Las censuras de la Real academia de la Historia intentaban justificar sus valoraciones négativas apoyándose en motivos pedagógicos, cuando lamentaban los ejemplos de «infeliz elección» en el David perseguido de C. Lozano. La obra daba al rey

el mismo carácter caballeresco y enamoradizo que pudiera darse a Roldán, Amadís de Gaula o el valeroso Esplandían usando aquel estilo impropio, redundante y Poético que dio motivo (entre otros) al St Tribunal de la Ynquisición para que proiviese la obra del P. Berruyer siguiendo las reglas de su expurgatorio ${ }^{28}$.

El mismo defecto de que adolecían las Conversaciones familiares de doctrina cristiana entre gentes del campo, artesanos, etc. original francés de Madame Le Prince de Beaumont propuesto para impresión en su traducción española; los agustinos del Colegio de Santo Tomás no encontraban proposiciones escandalosas, sino «ciertas cosas ridículas y otras mal digeridas, y lo principal falta de orden y méthodo en las materias, que propone» ${ }^{29}$.

Y qué decir de quienes echaban a volar la fantasía pretendiendo escribir una Descripción Crítica de París que

26 Censura de la Real Academia de la Historia, decisión del Consejo: «Escúsese la impresión» 7/I/1774. Impresiones 5534/7.

27 No ha lugar 24/XI/1759, Impresiones 5528/7. También caían en la misma culpa Almarza y su Catecismo ( «su autor quita, añade y altera el texto del padre Ripalda», según censura del arzobispo de Toledo), 22/II/1786, Impresiones 50674, y Botija, Gracias de la Concepción... en 1785, Impresiones 50674.

28 No ha lugar 1/VIII/1770, Impresiones 50664.

29 28/I/1773 Impresiones 5533,I/49. Se trataba de proponer la religión como fundamento de la educación y criticar el estudio de las novedades que sólo podían acarrear peligros para la sociedad. Véase SARRAILH, España... cit. pp. 219-220. 
No da idea de aquella Capital, ni de sus moradores, reduciéndose a una compilación de centones o especies sueltas, inconexas, las más de ellas vulgares, e insulsas, de ninguna instrucción y algunas equivocadas y notoriamente falsas y perjudiciales [...]. Alguna impropiedad en el idioma [...]. El Autor es Español y se halla pensionado por el Rey de Francia mezclando este becho serio, aunque no probado, con la relación de varias invenciones imaginarias, $y$ de diversas expresiones malsonantes que merecían examinarse por algún theólogo, $y$ probablemente suprimirse $e^{30}$.

Las censuras negativas del Consejo de Castilla en asuntos de religión, que en rigor deberían haber correspondido a la Inquisición, se explican en parte porque se trataba de textos que aún no habían salido a la luz, y por lo tanto no eran probibibles. Pero su razón principal era el hecho de que pudieran suscitar polémicas perturbadoras del orden público, por ejemplo al enjuiciar la potestad de la Corona sobre los bienes eclesiásticos, por el peligro que representaba la introducción del pensamiento de los philosophes - la tan temida Falsa Filosofía de Ceballos- - o que llevasen a dudar de la Inmaculada Concepción, o que sostuvieran el recurso a la luz natural —otra vez la filosofía, Forney y Wolff- o que predicaran el temible sistema del probabilismo, con sus nefastas implicaciones sociales ${ }^{31}$.

30 «Soy del dictamen que debe excusarse la publicación de este inútil Papel». Censura de Casimiro Ortega, 1/V/1782. Impresiones 50671.

31 Son varios los casos. Botija, Gracia de la Concepción... cit. Tras la censura negativa del maestro Salcedo y varios reparos de la Junta de la Inmaculada, la decisión del Consejo: «Archívese en la secretaría; y por la misma dese cuenta de todo al Sr. Conde de Floridablanca para que lo ponga en noticia de S.M.», 27/IV/1786. J.F. Cliquet, O.S.A. Apéndix a la Flor del Moral, reimpresión. Censura de Francisco Belza O.S.A. «Una sarta considerable de opiniones laxas, derivadas del falso sistema probabilístico" y consiguiente no ha lugar 4/III/1773, Impresiones 50667. De Maya Salaberría, Vida Sor Martina de los Ángeles... «Dejando los Fiscales al juicio de la Iglesia la Censura Theológica y ateniéndose a lo que en el Orden Civil exigen las leies del Reyno, la protección debida a la primera de las costumbres...» se pasaba a censura del Oratorio de San Salvador, negativa en 19/V/1772, Impresiones 50666. Rechazados también los Decreta authentica... con la censura di Joseph Cevallos catedrático de disciplina eclesiástica en los Reales Estudios en 2/XII/1773. Negativa, pues era una colección de falsos decreta, que la Congregación de los Ritos había condenado ya en 24/VII/1762. "Además muchos de estos son contrarios a las loables prácticas de la Nación y causaría escándalo, y confusión la reimpresión de esta obra viéndose reprovadas muchas cosas que practicamos», Impresiones 5534/64. Reimpresión del Directorio Moral de F. Echarri. Censura encomendada al colegio de Santo Tomás y parecer de los religiosos: «Hallamos que toda la obra es un Probabilismo puro, aunque se cubre el Author con el título de Anti-probabilista», 27/XI/1771, y no ha lugar 15/VI/1772. Sin embargo apelaba la decisión al consejo de Castilla y ésta daba orden de nueva revisión, en el Oratorio de San Salvador. Ahora el parecer era favorable y se concedía la licencia 12/I/1776, AHN Cons leg 1288, II/3. El Oratorio daba también censura favorable para las Cartas pastorales del arzobispo de Burgos, después de que su autor corrigiera ciertas «proposiciones dél [libro] falsas, malsonantes, erróneas y de peligrosa doctrina, y hace ver en su Apología o respuesta el buen uso que hicieron de aquellas y otras semejantes expresiones algunos de los Santos Padres en alabanza de la misma Virgen; pero haciéndose el prudente cargo de que el Pueblo no alcanza por lo común a discernir entre la diferencia que hay entre los hipérboles, y exageraciones que permite la Oratoria en los Panegíri- 
Con la actividad de la Imprenta Real los estándares de calidad de las impresiones se elevaron pues esa institución tenía por fin el interés público de la cultura y el económico de las ventas. Entonces se debía hacer notar que

Para condescender con esta solicitud [de licencia de impresión por la Imprenta Real] entiendo no basta que la obra sea regular, sino que es necesario sea excelente y original en su clase.

En cambio la obra El buen uso de la lógica en materia de religión de Muzarelli no valía nada, como decía Juan Facundo Caballero, director de la Imprenta, al Duque de Alcudia, secretario de Estado; y además hacía unas consideraciones en las que se mezclaban los motivos doctrinales con otros de carácter económico que habrá que tener en cuenta cuando se considere a la Imprenta Real como institución estatal de difusión de la cultura:

en confirmación de este juicio sólo diré que el pretendiente tiene licencia del Consejo para la impresión, y quando en estas circunstancias, ocurren a la Imprenta, es después de baver recorrido a todos los libreros, y no haver ballado quien se la tome, sin duda porque no la ban considerado de despacho, porque en esto sucede lo mismo que con otra qualquiera mercancía ${ }^{32}$.

Una vez revisados los expedientes de censura previa cuyo resultado fue negativo para el solicitante, es posible bosquejar los estándares culturales que los censores entendían requisitos mínimos para que una obra se publicara. La prudencia era una gran virtud, cuya ausencia impedía el éxito favorable cuando faltaba «la necesaria discreción» ${ }^{33}$. La imprudencia podía llevar a excesos que un censor no debía tolerar: "Impertinente, sacrílegamente fundado en la comparación y semejanza de la Ssma. Virgen con las Deidades del Paganismo» era el parecer de Fray Juan de Aravaca a propósito de la Oración panegírica... de P.

cos» por lo que se suprimía cuanto pudiera descarriar «a los lectores menos instruidos». 21/VI/1775, Impresiones 5533, I/74. Novena de Santa Gertrudis en la parroquia de San Miguel. «No es conveniente estender más esa devoción de lo que está; y basta que corran aquéllas que son de santos de la mayor devoción de los fieles, pues acaso se escandalizarían algunos si se las quitase enteramente», 1783, Impresiones 5547/63. A. Pérez, Relación bistorial... 24/VII/1777. Censura del Vicario General de Madrid: «en lo que no es dogma hay opiniones; el símil de la Capa para enseñar el más alto Misterio, y el de Cofradía para explicar lo que es la Iglesia, son muy reparables». "No se halla digna de imprimirse», no ha lugar 22/VII/1777, Impresiones 5540/16. El Juez de Imprentas censuraba negativamente a B. Trenco, Carta de un católico... porque ya había bastantes polémicas a propósito de las obras de Bonola, Impresiones 5563/65. Oficios de la Iglesia «Varias versiones de algunos oficios de la Yglesia, literales, y no para prácticas, que son las que se pudieron permitir por el Conssejo, después de nuevo examen", Impresiones 5550/70.

32 No ha lugar 18/VII/1794, AHN Cons leg 11281/27.

33 J. de Santa María, Historia del cautiverio... presentada en 1762, no ha lugar 31/VIII/1764. Impresiones 5528/12.

Hispania, LXIII/1, núm. 213 (2003) 161-198 
De Castro Bueno ${ }^{34}$. Se tocaban puntos religiosos delicados, hablaba de visiones que, para el censor, no tenían valor si no las aprobaba el director espiritual. En otros libros, aunque las materias tratadas eran «muy propias para excitar la piedad, y devoción, están mezcladas con otras especies, que no conducen a la edificación de los Fieles» ${ }^{35}$. La imprudencia en los asuntos de religión llevaba al maestro Juan de la Concepción del convento di San Hermenegildo a tronar contra F. De La Justicia y Cárdenas y su Papel nuebo joco-serio... ${ }^{36}$. Lo que más se deja ver en estas actuaciones es el recurso siempre usado por los reformadores laicos de querer presentarse como los auténticos intérpretes de la letra y el espíritu de la religión.

El llamamiento a la prudencia no era unidireccional. Igual que se condenaban las obras extemporáneas, sin ningún fundamento doctrinal, se dirigía también una recomendación al Poder para que lamentara, junto con el censor, el «deplorable estado de la razón en una de las más hermosas Regiones de la tierra»

Por lo que dexo a la prudente consideración de V.A. el que reflexione sobre la utilidad o el perjuicio que resultará de su publicación, respecto al estado en que se balla el estudio de la Philosophia en todo el resto de Europa, y al concepto que de nuestros Méthodos Escholásticos forman los extrangeros; acerca de lo qual me parece exponer que Mr. D'Alembert (doctísimo en estas materias) escrive en su obra con el título Mélanges de Litterature, d'Histoire et de Pbilosopbie tomo $4^{\circ}$ fol: 376 con estas palabras: Creerá la Potestad..

Quien esto escribía era una veż más Fray Juan de Aravaca, del Oratorio de San Salvador, en su censura a Alonso González, O. Premont. Curso de artes, en 15 de octubre de 1760 . Si el libro estaba lleno de contenidos nocivos, venía a decir el censor, era debido al pobre clima intelectual del país; a este clérigo ilustrado le dolía España en la medida en que las demás naciones europeas podían tener de ella una baja opinión debido a su nivel cultural y puede también caber la posibilidad de que la crítica verdadera de esta censura se dirigiera directamente a la poca doctrina de los religiosos ${ }^{37}$.

34 No ha lugar la licencia 20/XI/1759, Impresiones 50655.

35 Vida y virtudes de la Venerable Vicenta Contreras o F. De Jesús y Larrea, O.S.F. La vida arreglada... Impresiones 50654.

36 Rechazado el 17/X/1749, Impresiones 50645, e infinidad de obras de devoción que no eran del agrado de los censores, casi siempre regulares, como J. de San Joseph, O.S.F, Sagrada Novena a María Santísima... rechazada el 7/VII/1757 por sus «Proposiciones indecentes, torpes, escandalosas, temerarias», Impresiones 50654; Misterios que se cantan... rechazado en 1758, Impresiones 50693; Nuevo Romance espiritual... sin año pero 1761-1774, Impresiones 50694; Navarro y Belluga, Oración panegírica de San Juan Evangelista, no ha lugar 16/IX/1769, Impresiones 50663.

37 Sin embargo el Consejo de Castilla autorizó la obra el 31/X/1760, Impresiones 50656. Sería ocioso referir aquí todos los casos de censuras en las que se exige que el autor corrija la cantidad de errores que tenía su obra: recuérdense entre los expedientes de los censores Losada, Glorias de San Josef; Mendoza, Práctica atentísima; Oficio y Misa del Corpus; Richard, Sacrosantos Concilios... todos de 1790, en Impresiones 50676; Novenario San Joaquín, 1783, Impresiones 50672; Oloriz, Oración panegíri-

Hispania, LXIII/1, núm. 213 (2003) 161-198 
Aquí se introduce una de las preocupaciones de los ilustrados, ellos que tanto luchaban contra las preocupaciones de la gente inculta: «Contiene muchas tradiciones populares de poca, o ninguna verosimilitud $»^{38}$ que sólo eran «Equivocación, falsedad, o aplicación viciosa». Lo que se estaba condenando era el desfase cultural de la Península, como reconocía el capítulo de canónicos de San Isidro, a propósito de las Prelecciones teológicas de Gazzaniga, en 1793, obra sin criterio ni beneficio:

Mas como este defecto es general en casi todos los Autores de theología que manejan frequentemente los Profesores de nuestras Universidades

ello no era obstáculo para rechazar la licencia ${ }^{39}$.

El cambio significativo en los objetivos declarados de la censura preventiva se dio con el caso de Andrés y Sobiñas y su Resumen bistorial de la primera silla de Roma... que trataba de la elección de los papas. Lo curioso es que el autor había obtenido la licencia para la primera impresión en 1758 y ahora en 1769 quería repetirla; había que volver a censurar la obra, y el fiscal del Consejo indicaba que fuera la Real Academia de la Historia la que se encargara. Su parecer fue que «Era composición indigesta hecha sin conocimiento de las fuentes de la materia» y llena de tergiversaciones de los autores y fuentes usados que «promueven las tensiones ultramontanas citando con buena fee algunos heterodoxos: que en un tiempo tan ilustrado no era justo se autorizase una instrucción tan perjudicial». Por tanto el parecer de Campomanes era que no se debía reimprimir y que además se debían recoger los ejemplares de la primera edición. Este es un caso evidente de endurecimiento de la censura ocurrido a socaire de los planteamientos de política religiosa de la segunda mitad del siglo ${ }^{40}$.

ca, 1785, Impresiones 50673; Sánchez Valverde, Octavario de la Inmaculada... 1788, Impresiones 50675; Salazar, Afectos y consideraciones... Sierra, Ramillete de divinas flores... 1774, Impresiones 50668; Yepes, Vida virtudes y milagros Teresa de Jesús, 1775, Impresiones 50669.

38 F. Guerrero, Viaje de Jerusalén, Madrid 1644, reimpresión rechazada 1770, Impresiones 50664, y también el caso de la Carta Pastoral del Obispo de Ávila, 1780. El expediente inicia por una denuncia anónima, y genera tres informes: el primero reconoce una cierta proximidad con el Sínodo de Pistoya, mas no lo bastante grande como para justificar la condena. El segundo en cambio la abomina; además hay una tercera censura favorable con razonamientos no sólo teológicos sino también políticos. Recordaba que por mucho que el Sínodo se hubiera prohibido en Roma la bula de Pio VI «aún no se ha publicado en España» y por lo mismo la acusación no tenía fundamento. «Su asunto [la denuncia] es alarmar, meter fuego, e introducir y renovar en nosotros las disputas ruidosas, que se han ventilado sobre la materia con nuevos chismes, falsos testimonios y calumnias contra el próximo». La denuncia era porque se estaba «adulando, y confirmando los modos de pensar, y proceder de este siglo ciego e infeliz» según el delator. AHN Inquisición legajo 4428/18.

39 Impresiones 50684, 12/VIII/1795. En cambio el Vicario General de Madrid encontraba la obra excelente en 6/XII/1796. Así que la Sala de Gobierno tomaba una sabia decisión: «sobreséase en este expediente y pase a la Escribanía hasta que se solicite por las partes» en 9 de agosto de1805, lo que equivalía a condenarla al sueño de los justos.

40 Impresiones 5531/19, 2/III y 21/IV/1769. 
Para esta mentalidad política, ya no se trataba de impedir que obras poco meditadas pudieran perjudicar culturalmente al público o dañar la buena imagen internacional del reino, sino que había que evitar que los impresos pudieran poner en entredicho el orden social. El caso del Gran Piscator de Salamanca, Torres Villarroel, y el Pequeño Piscator, su sobrino Ortiz Gallardo, lo corroboran. Los dos habían «obrado paladinamente, pidiendo y obteniendo sus licencias de imprimir». Pero contaban

\begin{abstract}
sucesos políticos que pueden tener siniestra interpretación (...). Incumbendo al Magistrado político desterrar la ignorancia, la superstición y todo pretexto que pueda facilitar el menor embarazo a la pública Tranquilidad, o de facilitar medios para abusar del vulgo, procede se establezcan las reglas pedidas por el Fiscal, y en que abora insiste de nuevo que en los Kalendarios nada se toque de Gobierno, ni de sucesos Políticos, y se borren de los dos que acompañan todo lo perteneciente a estos asuntos ${ }^{41}$.
\end{abstract}

Eso ya se había dicho antes en las leyes que se referían a los asuntos de Estado. En 1767 la Real Academia de la Historia producía una autentica perla a propósito de la censura de las Cartas edificantes y curiosas... perla que se podía entender como marchamo para justificar cualquier prohibición de ideas que no se ajustaran al interés del poder:

Contemplamos como nocivas todas las noticias y expresiones que no se pueden conciliar con el sistema actual de Gobierno o con la pureza de nuestra Religión, y de la disciplina ecclesiástica [...]. Aquellos elogios y estas invectivas no pueden producir otro fruto que inspirar en la gente incauta o preocupada ideas viciosas y nada favorables hacia las acertadas providencias del Gobierno ${ }^{42}$

Se trataba de afirmaciones teóricas o enunciados de principio sobre las grandes líneas de lo que se podía o no se debía tolerar, siempre desde un punto de vista fuertemente autocrático. Pero también se daban casos concretos, como el del problema del tiranicidio, suscitado por ciertas doctrinas jesuíticas y amparado por las turbaciones sociales y la política religiosa de la segunda mitad del Setecientos. Censurando ciertas Proposiciones de la universidad de Barcelona, el fiscal del Consejo don Juan de Albinar, en junio de 1772, prohibía y confiscaba la obra, aunque más tarde el mismo fiscal aceptaría su difusión a condición de que se suprimieran las partes conflictivas, porque advertía que

en la primera [proposición $n^{\circ} 302$ ] expende la Doctrina de ser lícito al Vasallo matar al Príncipe en defensa de su propia vida y que por la misma Causa le es permitido berir o dañar; esta proposición impresa en Ydioma bulgar trae consequencias perjudiciales por las laxitudes que se suelen dar a tales Doctrinas, que no es justo enseñan a la Juventud de la

41 19/XI/1766, Impresiones 5529/8.

42 Impresiones 5529/15.

Hispania, LXIII/1, núm. 213 (2003) 161-198 
Provincia de Cataluña, y aun coincide con la Doctrina del regicidio, y sobre todo, queda el mismo Vasallo agresor árbitro, y Juez para bonestar su propio becho ${ }^{43}$.

El concepto de orden público se mezclaba inmediatamente con el de actividad política en todos los casos en que la difusión de cualquier tipo de idea podía poner en entredicho el status quo o la práctica de gobierno. En este campo espinoso los manuscritos clandestinos eran, según algunos historiadores, auténticos ejemplos de «literatura militante» y seguramente tenían muy escaso valor literario, pero eran colecciones de argumentos en pro o en contra de ciertos temas actuales de importancia social que era mejor no tocar ${ }^{44}$,aunque a veces algunos textos querían salir a la luz pública. En 1772 los fiscales del Consejo, tras la petición de licencia del Elogio Fúnebre del Obispo de Cuenca, declaraban no encontrar en él nada reprochable; la actitud personal del prelado siempre había sido «muy digna y mucho más fue recomendable su vida privada, sus penitencias, su caridad y su desapropio». Pero el «maior cuidado» debería ponerse en «algunas expresiones» que pudieran

interpretarse tal vez contra la mente del orador [Felipe Montón y Romero, abad de Santiago]. Bien presente tiene el Consejo las representaciones que al tiempo de las turbaciones pasadas dirigio este Prelado a S.M. sindicando la conducta política del Gobierno.

Según los fiscales se debía imputar el hecho «a la ingenuidad» del religioso en cuya boca habían puesto afirmaciones injuriosas unas "personas desafectas». Así, unos años después de los acontecimientos, se reescribia toda la historia intentando minimizarla y dejando bien salva la autoridad real. El Consejo hacía otros apuntes también: el título del discurso, La muerte en vida o vida triunfadora de la muerte pudiera inducir a «una idea de persecución del Prelado»; y se remachaba la posición de una lectura política de la vida del obispo pues el Consejo hacía notar que se dedicaba la obra «a la piadosa inmortal memoria...» pero para los fiscales «no es cosa gloriosa incurrir en unos hechos que dieron motivo a la justa severidad de las leyes, ni debe mirarse como inmortal la fama que de esto le resulte». El autor, en su dedicatoria, declaraba de la vida de Carvajal "que sólo tiene contra sí el borrón de quien la escribe» pero los fiscales eran implacables en su comentario: «Luego no mira como falta los hechos que dieron motivo a la concurrencia de este Prelado y le califica de inocente en ellos, y por consiguiente como desarregladas las providencias tomadas a Consulta del Consejo pleno». Montón y Romero llamaba a su biografiado «Oráculo de los aciertos» y la contestación de los fiscales era lapidaria: «Seguramente que las

43 Impresiones 50666. El concepto de tiranicidio era puramente político en el pensamiento de otro importante autor, Ceballos, y su Falsa Filosofía, contra el racionalismo ilustrado y contra el absolutismo regio, porque rechazaba el predominio de la Corona sobre la Iglesia. Sobre la formulación de este pensamiento político, fuertemente antiestatal, véase ÁLVAREZ JUNCO, op. cit. pp. 336-337.

44 BENÍTEZ, M.: «De arte compilatoria. La manufactura de manuscritos clandestinos», Censura e Ilustración, Un. Santiago de Compostela 1997. 
cartas dirigidas a S.M. por el Reverendo Obispo se contradicen con este epitecto» y tampoco se perdonaba que se lo presentara como «Zeloso defensor de las mejores costumbres», pues el prelado «reprehendía muchas acertadas máximas del gobierno como perjudiciales introducciones, manifestando en esta parte menos discernimiento del necesario». En esto residía el verdadero alcance de la censura porque se negaba que se pudiera poner libremente en circulación el panegírico de quien había atacado duramente las medidas de gobierno tómadas por los ministros ilustrados en asuntos de política religiosa. De nada valía reconocer que «jamás cometió pecado mortal alguno, expresión que coincide con la inocencia de que se trató en la cláusula de la dedicatoria» pues sus pecados eran políticos ${ }^{45}$. Semejante en sus planeamientos es el caso de Fray B. de Cárdenas y sus Sermones, en los que se proferían expresiones contra el Correo de Ciegos del 28 de febrero. La Sala de Alcaldes mandaba abrir un expediente al fraile, capuchino de la Paciencia, por atreverse a criticar una publicación autorizada por el Consejo. Preguntado, informaba el alcalde: el religioso no se dirigía "contra la autoridad del Gobierno, ni de sus Magistrados» por lo que la Sala no veía razones para tomar medidas contra el sermón y su autor, pero la Cámara decidía indicar al autor

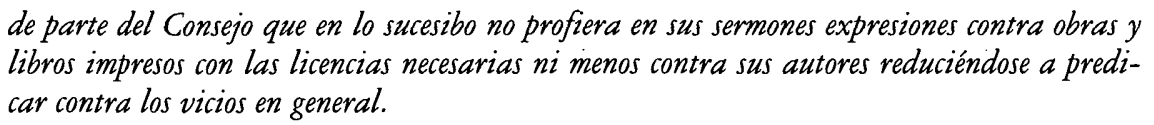

La culpa del capuchino consistía en haber criticado la propuesta del Correo de establecer hospitales para mujeres con enfermedades venéreas, argumentando que la enfermedad era el castigo de Dios por sus vicios ${ }^{46}$.

El censor siempre estaba alerta, porque el error podía esconderse en cualquier texto, incluso en el que otrora estuviera justificado por lo calamitoso de los tiempos, pero que reeditado en nuevas circunstancias políticas y sociales podía reavivar los rescoldos de pasadas polémicas. Así ocurrió con la obra del jesuita Ribadeneyra, Tratado de la religión, publicado en 1595, porque en los primeros capítulos se apreciaban

algunas dudas por contenerse en ellos doctrina que me parece ser contraria a la Soberana independencia, magestad, y regalías de los Principes Cbristianos y principios de un zelo, que aunque en aquellos calamitosos siglos pudiera baber sido discreto, y en el día sólo babrá de servir para alzar de nuevo el fuego de la persecución, el fanatismo, la intolerancia civil, $y$ el odio entre las naciones y los bombres ${ }^{47}$.

Hay una enorme masa de documentos sobre censuras negativas por acusaciones de turbar el orden público, de los que se pueden recordar algunos casos.

45 15/I/1772, Impresiones 5531, I/61.

46 10/III/1787, AHN Cons lib 1376 ff. 1360.

47 Debía expurgarse y corregirse por censura de la RAH 22/X/1784. Impresiones 50673.

Hispania, LXIII/1, núm. 213 (2003) 161-198 
El del mismo Campomanes en 4 de octubre de 1759: «¿No sería más fácil a este Autor traducir unos tratados de los quales saca quanto tiene de fundamental, que no producir una apología que sirve sólo para conmover los ánimos sobre una obra que aún no hemos visto?». El autor levantaba polémicas donde no las había, según su censor. O el de Seguí de Capella y Casanova, Noticia del Escudo de la Concordia...: «Estas obras anuncian diferentes Suzesos políticos en forma de adivinanzas, que pueden tener siniestra interpretazión, y su leyenda perjudicial al público». También la censura del fiscal a Isidoro Ortiz Gallardo, Embajada de los astros, 1766, y a su tío Diego de Torres Villarroel, La tía y la sobrina, e igualmente, el 29 de septiembre de 1735, para El mayor plenipotenciario... obrita presentada por Pascual Aznar. Por las mismas consideraciones se denegaba la licencia de impresión «dexando advertido a su Author, porque en adelante se abstenga de tomar la pluma a semejantes empeños, sin tener muy a la vista las atenciones correspondientes al Decoro, y Veneración conque se deben tratar los Designios de los Reyes» a A. De Urritigoiti, Concordia de Europa... ${ }^{48}$

Con los acontecimientos de la Revolución Francesa el grado de severidad de la censura, en lo que se refiere al orden público, aumentó aún más si cabe. Pagaba por ello José de Campillo con su Lo que hay de más y de menos en España en 1794, en el informe del censor Fray Bernardo Rozados, lector de teología en Nuestra Señora de Atocha. La obra no debía publicarse porque tocaba materias de estado, y

Sería además nociva en las actuales circunstancias [...]. Hace temer que aquí anda oculta perversa mano de alguno, o algunos descontentos con el actual Gobierno, y por consiguiente, siendo también de recelar que se dé también a otros la censura de las mencionadas Obras, lo es también que no falte alguno o algunos que o mal intencionados quieran con su Aprobación fomentar revelión de la Nación a el Gobierno Monárquico reputado tyránico por algunos pues no faltan Jacobinos en España,

y recordaba el Real decreto de 4 de febrero de 1735, que se refería sin embargo a la autorización necesaria para publicar obras sobre manufacturas e industrias, cuando estaba censurando desde el punto de vista de la propagación de las ideas políticas más recientes ${ }^{49}$. La monomanía de la amenaza jacobina en el

\footnotetext{
48 Respectivamente en Impresiones. 50655, 1766; Cons leg. 50693 y leg. 50631, y 3/XI/1735, censura de Antonio Téllez de Acevedo, Cons leg. 50631. Los subrayados son míos. También HerreRO, J.: Orígenes del pensamiento reaccionario español, Madrid 1971, cap. IV, «Los discípulos españoles: Zeballos, Rodríguez, Valcarce» (pp. 91 ss.). Son los seguaces españoles de Bonola y Nonnotte: Ceballos, Falsa filosofía, 1775-1776, subraya la peligrosidad de la filosofía moderna para la sociedad tradicional; «El oráculo»; Rodríguez, Filoteo, 1776; Fernández Valcarce, desengaños filosóficos, 1787-1790.

49 Libro I Título VII Auto 32, Autos Acordados, AHN Estado leg 3014, 7/IX/1794. Sobre Campillo y su Lo que bay de más y de menos en España de 1741, véase DOMERGUE, La censure cit. pp. 43-45, donde es llamado "golilla en mal de réglamentation"; RodríGUeZ Villa, A.: Patiño y Campillo, Madrid 1882, pp. 101-106 habla del personaje con más simpatía; STIFFONI, "Intelectuales...»
} 
reino, como se ha podido comprobar, se remontaba a mucho tiempo atrás, si se acepta la identificación entre revolucionarios y «descontentos con el actual gobierno». En el mismo año de 1794 se presentó también la petición de licencia de impresión para el Correo de Bayona en Francia que se quería traducir y vender en España. Aunque al considerar el caso parecería una empresa descabellada dada la situación del momento, el Conde de Isla, Juez de Imprentas, tardó ocho años en tomar una decisión que naturalmente fue negativa y rechazó la petición bajo el pretexto de que no se garantizaba la continuidad de la obra, pero con la razón evidente de que sus autores estarían sometidos a una legislación distinta de la española ${ }^{50}$. Verdaderamente estaba más clara la censura al tratado de Campos De la desigualdad personal, compuesto durante su encarcelamiento en el castillo de San Lorenzo de Málaga entre 1799 y 1800 . Ya el título habla de por sí de lo que trataba la obra, y por lo mismo se la rechazaba porque

la obra vale poco, y si así no fuese no pudiera ni aun soñar en escribir en tales materias.

El censor solucionaba el problema del sueño de la razón: para evitar los monstruos que produce era suficiente prohibir que se soñara ${ }^{51}$. Con estas tomas de posición el pensamiento ilustrado cerraba el circulo de promoción de la cultura que había emprendido tímidamente, para reafirmar los principios más tradicionales de sus antiguos adversarios.

Por mucho que sea imposible justificar lo injustificable, la sensibilidad social del Dieciocho era muy distinta de la actual y Poder y censores encontraban maneras de razonar su actividad. Las motivaciones políticas de defensa del status quo se velaban con consideraciones de orden público, la mordaza a la producción de obra polémicas se justificaba con el afán de evitar reabrir viejas heridas... Pero también campeaban entre los censores la vocación y dedicación pedagógica, lo que no será de extrañar por otra parte, estando a la extracción profesional de quienes se ocupaban de la calificación de los libros, profesores y eruditos. El asunto era que para una cierta obra

$$
\begin{aligned}
& \text { puede ser perjudicial su impresión si los lectores no comprebenden el designio de su Au- } \\
& \text { tor, en cuyo caso en lugar de mejorar las costumbres puede corromperlas }
\end{aligned}
$$

según le pasaba a Ropesi con sus Diálogos críticos e irónicos en 1774 . No se concedía la licencia porque debía cambiar la presentación de sus argumentos para hacerlos más inteligibles ${ }^{52}$. Se trata del problema, tan invocado por los censores, del estilo, y en su nombre, por faltar de

\footnotetext{
cit. Lo que hay de más y de menos en España... censura de Fr. Bernardo Rozados, lector de teología en $\mathrm{N}^{\mathrm{a}} \mathrm{S}^{\mathrm{a}}$ de Atocha. Obra indigna de la imprenta porque toca materias de Estado.

so 27/VIII/1802. Era materia de Estado, en AHN Cons leg 11284/14.

51 «Tiene además mucho plagio, y de esto no debe tratarse directa, ni indirectamente». AHN Estado leg 3014, julio de 1800.

s2 20/IV/1774, censura RAH; No ha lugar 1/VIII/1774, Impresiones 5535/6.
}

Hispania, LXIII/1, núm. 213 (2003) 161-198 
furor, o entusiasmo Poético, ni estilo, frase o concepto

se podía rechazar una licencia, como le ocurrió a Diego Rejón de Silva en 1769 aunque su libro no contenía nada ofensivo a la moral o a las buenas costumbres:

Es éste un escrito de los muchos que en este siglo produce el desmedido anhelo (ya casi endémico en Nuestra Peninsula) que tiene aun el menos proporcionado, de que vuele su Nombre Impreso por el Orve (prurito a la Verdad que no deja muy bien puesta la Nazión con las extrangeras ${ }^{53}$.

Entre los censores hay algunos que, en teoría, deberían ser autoridades en materia, porque eran ellos mismos escritores; en la serie de Impresiones se hallan censuras negativas de José de Cadalso a V. Viscaíno, Quejas legales... en 1772, Casimiro Flórez Canseco, autor de la Carta de Antheo Mantuano, censurada por el Consejo en 1791, y anteriormente censor de F. Gómez de Quevedo, Paráfrasis de las obras de Anacreonte Feyo en 1785, y del Galateo o arte de la buena crianza, en 1779. También censuraba Leandro Fernández de Moratín, en 1797, a M. De las Mercedes Gómez de Castro, Pintura del talento... y Vicente García de la Huerta daba su parecer sobre la obra de Cabaza, con el alias de Feijo Asdroazavaci, Paquebot de corte, Triumvirato de la Corte, en 1785. El mismo literato también se encargó de censurar negativamente a J.I. Cavara, Los españoles reconocidos a su rey, en 1784, y a J. Menchenn, Declamaciones... en 1786.

$\mathrm{Y}$ al enfrentarse con la pureza de la lengua, los censores tropezaban con las traducciones, y se cebaban en ellas, pues no reflejaban debidamente o la variedad del original, o la riqueza del español: buenos pretextos, en realidad, para impedir la difusión de ideas importadas. Una vez más habrá que pensar que estaban perfectamente cualificados para emitir sus juicios pues más de uno también era autor de traducciones pero resulta que en algunos casos se habían rechazado las licencias a sus propias obras. Alguacil alguacilado quedó B.J. Pérez Pastor, que censuró negativamente en 1791 el Diccionario abreviado de autoridades, pero, como autor, había sufrido la censura negativa del Consejo de Castilla a su Rodrigo o el demonio casado, en 1790. A la vista de lo cual el problema que se presenta inmediatamente es el de la autoridad de los censores, en su sentido de autoridad intelectual o de capacidad profesional. Los datos indican que entre 1724 y 1799 el Consejo de Castilla denegó 633 peticiones de licencia de impresión, de las cuales sólo 25 aparecen sin datos sobre el censor que clasificó la obra; de los 608 casos conocidos, sólo el 34,7\% tuvieron por censor un organismo intelectualmente especializado, si por tal se puede aceptar la Academia Médica de Madrid, o el Colegio de Abogados, o los colegios de

53 Impresiones 5530/19, 1779. «No merece salir a la luz pública, por estar escrita con mal estilo, y peor ortografía y llena de razonamientos difusos»; Un parecido «escúsese» el 16/III/1779 a F.J. Cid, Memoria sobre un parto... en Impresiones 50672. 
Santo Tomás y San Isidro, o finalmente las Reales Academias Española y de la Historia, ésta última con la censura de 114 textos, lo que hace de ella una de las palancas más importantes del gobierno para su política cultural. Ahora bien, dado que a los censores se remitían textos de cualquier asunto, queda muy en entredicho la capacitación especializada de sus dictámenes. Y también está el caso contrario, esto es el de los organismos cuyos miembros no tenían más preparación cultural que la que se les quisiera presuponer, y que dictaminaban en base a todo tipo de criterio y sobre cualquier suerte de asunto, como el mismo Consejo de Castilla, con 104 censuras sobre los más variopintos asuntos, lo que representa el 17,10\% de los casos, o en Vicario General de Madrid, que remitió 133 censuras negativas, no siempre y no sólo de obras teológicas o de religión, el $21,8 \%$ de todas las censuras negativas emitidas. Estos hechos pueden explicar la gran variedad de criterios aplicados en el momento de evaluar un texto.

La Academia de la Historia, por ejemplo, reconocía que el Compendio de la bistoria antigua de Duchesne era un inofensivo librito elemental de historia, pero he aquí que la traducción no tenía

\section{la exactitud y propiedad que pide la buena locución castellana en la parte prosaica}

lo que era razón suficiente para rechazar la licencia ${ }^{54}$. Ligeramente distinto, por su resultado, el caso del padre Cellier y su Biblioteca selecta de los SS.PP, «Obra que tiene a su favor el voto de los más sabios críticos de la Europa» pero en la que «se ha ligado [el traductor] demasiado al original, vendiéndonos muchos Galicismos por frases de la lengua Castellana». Sugería al Consejo «disimular» dado el gran valor del texto, y la decisión: «Debuélvase la obra al traductor para que de acuerdo con el Censor la arregle y corrija los Galicismos que dice tiene» $\$ 5$. Es evidente la importancia del francés y de lo francés en la sociedad

54 18/VIII/1792, AHN Cons leg 11279/100. También J. Croiset, Horas espirituales trad. Benito de Castro, presbítero, 1778. Censura del Vicario Eclesiástico de Madrid, 14/X/1778, Impresiones 50671. Según el satírico autor de la Carta de Don quijote... había que preguntarse «si se habían acabado en España los hombres capaces de componer obras originales, puesto que los más se dedican a traducir». Se nota el movimiento de malestar causado por la abundancia de traducciones de obras extranjeras, y por lo mismo, a los ojos del celoso censor, peligrosas. Y además, en palabras de Santos M. Pariente y Celis Cartas y Observaciones, (citado por AGUILAR PIÑAL, F.: «Las academias», Historia de España, ed. J.M. Jover Zamora, XXIX, II, Madrid 1985, p. 190 y nota 10), «los más de ellos [traductores] sin saber la gramática latina, francesa, italiana ni española ... y sin saber de regla alguna de traducir, nos ofrecen todos los días libros de versión tan depravada que se necesita otro traductor de aquella traducción». También Acant, Miscelánea... 1790, Impresiones 50676. «Formé el juicio de que eran retazos traduzidos del Francés, sin elección ni crítica; y en el progreso de la lectura he confirmado la realidad de mi discurso, pues además de que el estilo y pensamiento lo indican, se ve a cada paso que el primitivo autor no sólo era francés, sino que escribía dentro de París mismo, lo qual no reparó el traductor preocupado en vestirse galas agenas para hazerlas pasar por propias» según censura de Francisco Cerdá y Rico. «Escúsese» 9/II/1790.

s5 4/V/1791 Impresiones 50676.

Hispania, LXIII/1, núm. 213 (2003) 161-198 
española del Setecientos, como ponen de manifiesto algunos interesantísimos trabajos sobre la influencia de Francia en la cultura española. Aquel país era el modelo y la guía intelectual de las élites pensantes de la Península. Como ha dicho Fuentes, «Lo francés define, por partida doble, a las clases dominantes españolas». Buen ejemplo es el caso de Marchena, en 1787, quien no encontraba otra solución para salvar el buen gusto en el teatro más que subir el precio de las entradas para evitar la presencia del populacho. En otros aspectos, como era de esperarse, la galofobia era típica del $\mathrm{clero}^{56}$. De tal modo se realizaba la mezcla de motivos casticistas en lo lingüístico con la defensa de las posiciones políticas más tradicionales en lo social.

Así que las traducciones era generalmente del francés, con un aplastante $62 \%$, lo que una vez más indica cuánto debe la cultura española del Setecientos al país vecino, pero también se traducían - y se rechazaban, porque el cuadro 1 sólo refleja los textos no autorizados - de otras lenguas: del latín, los inevitables tratados religiosos y teológicos, y del italiano, con un $25 \%$ de todos los casos. La presencia de obras portuguesas e inglesas es puramente anecdóti$\mathrm{ca}$, por su escasa incidencia. Desde luego que los porcentajes de traducciones rechazadas reflejan bastante fielmente las influencias reales del pensamiento europeo en la cultura española del siglo XVIII, y reflejan también que esa influencia fue muy acentuada: la cuarta parte de lo rechazado era originario del extranjero. Profundizando en el análisis cuantitativo, se puede notar que las traducciones - y su consiguiente rechazo- dependían de la actualidad de su asunto, o al menos así lo hace presuponer el hecho de que de las 95 traducciones del francés rechazadas en los últimos setenta y cinco años del siglo, 25 lo fueron en tres solos años, es decir 6 en el año 1790, 12 en 1791 y 7 en 1797. Por los títulos de lo rechazado no se puede argüir que se tratara de textos de política, por lo que se debe admitir que la censura se endurecía con las obras francesas sencillamente por su procedencia. Este hecho hace pensar sobre la competencia literaria de los censores, pero no deja dudas de su eficacia policial. Y es tanto más indicativo en cuanto que, como se verá más abajo, los factores literario-estético-estilísticos se invocaban a mansalva para justificar las censuras negativas. Ahora bien, si se compara la suma de las versiones no admitidas por la censura previa con el total de las obras traducidas sólo de teatro de que hay constancia, se notará que su peso en relativamente pequeño. Se cuentan 937 ediciones de piezas teatrales entre francesas, 587, italianas, 348, e inglesas, 2.

56 FuENTES, J.F.: «Moda y lenguaje en la crisis social del Antiguo Régimen», La imagen de Francia en España en la segunda mitad del siglo XVIII, edición J.R. Aymes, Alicante-París 1996, p. 85. Más de una voz mostraba su inquietud por la proliferación de usos lingüísticos tomados del francés; incluso el término "galicismo" se entendía de manera peyorativa, y se usaba ese rasgo formal para condenar la introducción de actitudes o valores reformadores o innovadores. En realidad el problema, como habían denunciado Feijoo y Vargas Ponce, era que los traductores eran incompetentes. ETIENVRE, F.: «Le gallicisme en Espagne au XVIIIe siècle: modalités d'un rejet», La imagen de Francia en España en la segunda mitad del siglo XVIII, edición. J.R. Aymes Alicante-París 1996, pp. 103 ss.

Hispania, LXIII/1, núm. 213 (2003) 161-198 
El total de las traducciones rechazadas representan el $16 \%$ de las obras de teatro autorizadas, es decir una fracción mínima de las versiones aparecidas en español ${ }^{57}$.

CUADRO 1. Traducciones rechazadas según la lengua original 1724-1800

$\begin{array}{lrr}\text { Total traducciones } & 150 & \% \\ \text { Francés } & 94 & 62,6 \\ \text { Inglés } & 4 & 2,6 \\ \text { Portugués } & 6 & 16,6 \\ \text { Latín } & 21 & 14,0 \\ \text { Italiano } & 25 & 4,0\end{array}$

De hecho, al considerar la enorme cantidad de casos recogidos en los registros de la serie de Impresiones del archivo Histórico Nacional salta a la vista que los criterios de estilo eran razón suficiente, a los ojos del censor, para impedir la difusión de un escrito. Se ha intentado estudiar cronológicamente las censuras negativas por razones de estilo, aunque no se ha podido notar ninguna evolución en los criterios, ni siquiera homogeneidad en los mismos. En 1764 el párroco de San Sebastián de Madrid, Diego Caballero de Arriaga, sorprendentemente decía en una censura suya que

Aunque bay mucho fárrago inútil, e impertinente para su asunto, y muchas expresiones mordazes, y muy picantes, que juzgo por prezisas, y nezesarias para condigna satisfacción al impreso [era la respuesta polémica a otra obra] que impugnan, e estar éste con las lizenzias necesarias, y contener abominables expresiones, y considerar las de estos escritos, por un Juguete de Vozes, terminando en ellas toda la Saña de estos escriptores, no juzgo que este desmerzca la lizenzia que pide, dada, como se dio al contrario.

Es decir, que miraba con gran benevolencia las polémicas entre escritores, que no pasaban de ser, en su opinión, un «juguete de voces» y eso a pesar de que dichas voces no eran siempre todo lo elegantes que debieran e incluso si después juzgaba intolerable el ataque que se hacía a los jesuitas ${ }^{58}$, pero pocos años antes, en 1746, el revisor de comedias Bernardo Joseph de Reinoso había clasificado de "horrendo desatino", "ni en verso ni prosa, ni estilo vascongado»

57 Teatro europeo en la España del siglo XVIII, edición F. Lafarga, Lérida 1997.

58 Censura a J. De Azpeteguía, Agur del bascuence... 16/VI/1764, y no ha lugar del Consejo de 25/VI, Impresiones 50660.

Hispania, LXIII/1, núm. 213 (2003) 161-198 
la Loa... de García de Mendoza ${ }^{59}$. Y en 1741 el censor decía exactamente lo contrario que su colega de 1764 a propósito de El saludador de los astros... pues

se compone de Chocarrerías perniciosas, Vozes impúdicas, Sátiras indegentes, y sobre todo de un cúmulo de desatinos sin concierto, sin discurso, sin agudeza, chiste, ni dibersión alguna ${ }^{60}$.

¿Ahora no eran juguetes las voces del libro? Al final en la censura sólo cabían, a pesar de las leyes y directrices políticas, las opiniones del censor. «Me parece la cosa más a propósito que se puede imprimir para formar Gerundios» decía Miguel Alvira del Oratorio de San Felipe Neri de la obra de un fraile franciscano, poniendo en relieve su pésima calidad literaria ${ }^{61}$. Con las mismas razones se rechazaba en 1774 la Oración panegírica... de J.T. Boil, con censura de Miguel de Cervera: era obra rechazable "porque se valen de la Sagrada Escritura al son-sonete que es lo que el vulgo llama: Gerundismo» ${ }^{62}$.

Lo más curioso es que estos defensores de la perfección del idioma no eran miembros de la Real Academia sino simples particulares, a quienes se habían encomendado tareas de censura pero ciertamente no para fijar, pulir y dar esplendor. Sería de suponer que la de la Historia tuviera otros criterios de calificación científica, pero en 1785 encontraba expresiones ridículas y «mal estilo y peor gusto que muestra en todo su escrito" al valorar a Herbella de Pugo, Ciencia de estado ${ }^{63}$. Igualmente dictaminaba la Academia Médica Matritense ante el Compendio práctico ... de O'Cullinam, «Por observarse en ella un estilo confuso, notable impropiedad en las voces, falta de orden y método, y tratando de las más enfermedades en general, no da a conocer las distintas especies" y decretaba que no debía imprimirse. Por lo menos en este caso una de las faltas de la obra era de tipo técnico, aunque la impropiedad del estilo era determinante para mandar que se corrigiera ${ }^{64}$. Evidentemente las imperfecciones lingüísticas sólo eran un pretexto para impedir la difusión de un texto, o, si no, ¿cómo justificar que se rechazara la licencia de la Oración... de 1769 con la especie de que «Hallo que no observa el méthodo y orden de la debida oratoria,

59 Con su consiguiente no ha lugar 17/X/1746, Impresiones 50642. D. García de Mendoza, Loa, en que sorteando por una quenta y su Regla general las letras del abecedario se descubre por digno objecto en el theatro de España nro. Catbólico Monarcha D. Felipe el Sexto, 1746.

${ }^{60} \mathrm{~J}$ De Moraleja, rechazado 4/IX/1741, Impresiones 50637, o J. Menéndez y Sanz, Introducción al vergel... rechazado por «sin arte», 28/II/1766, Impresiones 50691.

${ }_{61}$ Joseph Morales de la Encarnación, O.S.F. Quodlibetum concinatorium... 7/VII/1758, Impresiones 50654 .

62 Subrayado en el original, 15/VI/1774, Impresiones 50668; por la misma nota de sonsonete se rechazaba en 1777 la publicación del Sermón de la dolorosísima pasión... predicado en 1765 por Fray Antonio Francisco Zuazo, con censura del Colegio de Sto. Tomás, 11/V/1775, Impresiones 5537/80. Y por «Bajo estilo», F. Tamayo Morales, Aurora de la Ley... 1758, Impresiones 50654 . Más casos en leg. $5531,1769-1770$

63 24/XI/1790, Impresiones 50676.

$6410 / \mathrm{VI} / 1785$, Impresiones 50673 .

Hispania, LXIII/1, núm. 213 (2003) 161-198 
ni usa debidamente de la escriptura» o por ser «Uno de los libros más mal escritos de quantos he visto en este género» según el Colegio de Santo Tomás, cuando se echa un vistazo, aunque somero, a lo que era la producción media de aquellos años, a lo que se imprimía impunemente? ¿Por qué el tono destemplado de la censura de Romero, Aventuras de Don Gerónimo de 1790,

Lectura tan inútil, desabrida, y susceptible a la imaginación de escándalo y asco [...] Cachos de caprichos disparatados e inconexos

que había que rechazar por indecente y soez?65. Una posible explicación es que los censores usaban, no pocas veces, de su poder para ajustar cuentas con enemigos personales, políticos o religiosos, y después se escudaban en los dictámenes de la Academia, como el que ésta emitía para la Función de las parejas... de De La Ballina en 1770. La institución trabajaba pro domo sua:

No se puede dudar que el Consejo tenga por fin en estas remisiones a la Censura de la Academia, el promover la eloqüencia Castellana, y evitar salgan a la luz pública, como por desgracia ba sucedido largo tiempo, obras de lenguaje extraordinario, faltas de propiedad, elegancia y pureza en el estilo que absolutamente ban contribuido no sólo a transformar la verdadera eloqüencia sino a corromper el idioma ${ }^{66}$.

Aunque desde luego las numerosas y reiteradas leyes de imprenta no se destinaban precisamente, en su articulado, a esa finalidad, los censores hacían sus pinitos de críticos literarios, como Don Francisco Cerdá y Rico sobre Guillén de Castro:

Las dos comedias de las mocedades del Cid escritas por don Guillén de Castro, y aunque es verdad que no están del todo libres de los defectos que son tan comunes a nuestras piezas dramáticas, sin embargo son superiores en el mérito a muchas de las de Lope de Vega, Calderón, y otros que corren con aprecio [...] Excelentes preceptos de moral y curiosas noticias bistóricas

y con tan autorizada opinión Nava concedía la licencia ${ }^{67}$, aunque, nótese bien, tenían defectos; pero sus preceptos morales eran excelentes. «No confundas lo grave con lo hinchado» decía de la tragedia y por ende del buen estilo J. De pisón y Vargas. Alertaba contra la pedantería y la pomposidad; "Con orden y elección has de entregarte / a modelos sublimes y escogidos / que observan

\footnotetext{
65 «Su impresión sólo puede servir para hazer ver que aun está mui atrasada la eloquencia christiana en estos Reynos» 1773, Peris, Sermones de Cuaresma, Impresiones 50667; Don Gerónimo, 30/VII/1790, Impresiones 50676. También L. Adandrat, Oración en la fiesta [...] al gloriosísimo San Ysidro... Censura del párroco de Sta. Cruz, y no ha lugar 12/VI/1769, Impresiones 50663.

66 1770, censura Real Academia Española de la Lengua. Impresiones 5532, II/55.

$67 \quad 23 / \mathrm{XI} / 1779$ Impresiones 50683.
}

Hispania, LXIII/1, núm. 213 (2003) 161-198 
propiedad, pureza y arte». ¿Cuántas de las obras publicadas con beneplácito de la censura gubernativa respetaban tales preceptos? ${ }^{68}$

Otro teórico de la traducción, y por ende del estilo más adecuado para componer en español, era Filonoo. Primero de todo reconocía la decadencia de la ciencia y la cultura españolas; después la atribuía a la corrupción del estilo, en el Barroco (pp. 26-32); llegado a este punto, el último paso que le quedaba consistía en censurar el «lenguage ininteligible, y una algarabía fastidiosa» ( $p$. 32) debido a las traducciones, sublevándose contra la imitación pedante «del decir de los vecinos». «La culpa tiene esa indiscreta turba de Traductores, que parece haber sido enviada, qual exército de langostas, a arrasar el ameno país de la literatura» (p. 32).

La lengua castellana [...] desfigurada en un todo, perdida su natural gravedad, lánguida, sin nervio, sin viveza $(\text { p. } 38)^{69}$.

¿Pero qué remedio proponía? El retorno al ejemplo de los clásicos, como era de esperarse. Los antiguos griegos

el estilo que emplean es grande y elevado; pero esa grandeza y elevación, no tanto se debe a las palabras, [...] como al diseño y composición de toda la obra, en la que con una noble naturalidad se nota una viveza llena de gracia y atractivo (p. 26).

Había otra condición para obtener la licencia de impresión de parte de la censura del Consejo de Castilla. La obra que se deseaba imprimir no podía excitar los ánimos, debía respetar las leyes del buen estilo, y, por último, había de ser útil. Ésta es la tercera de las columnas que soportaban el edificio de la Ilustración: concordia social, estética y provecho, principios mil veces proclamados y casi otras tantas traicionados en la práctica política de cada día. Es un concepto presente en el Dieciocho como elemento justificador de los proyectos reformadores de la nueva dinastía, que "pretendía ser útil a la sociedad, ser el instrumento impulsor de medidas que elevarían los niveles de seguridad y bienestar de sus súbditos; dicho en términos de la época, pretendía actuar a favor de la felicidad pública» ${ }^{70}$.

68 Ofrecía como espejo a los literatos «Raquel [García de la Huerta], el Delinqüente honrado [Jovellanos] y la Numancia [Cervantes]». Las tragedias contemporáneas eran superiores a las antiguas, sanguinarias y «más que de freno, de corrupción a las costumbres». Alabanzas a Luzán. J. De Pisón de Vargas, «Al lector», La Elmira (trad. de Voltaire, Alzire) 1788.

69 En realidad protestaba sólo contra los malos traductores. A. Filonoo, Desengaño de malos traductores, Madrid 1786. Él mismo había censurado la traducción de Louis Racine, Poema de la Religión, «hecha por un capitán de caballos, socio de mérito de las reales Sociedades Bascongada y Aragonesa» y escribía su Desengaño... precisamente para explicar lo que no había que hacer al traducir. J. de Cadalso, Los eruditos a la violeta, Madrid 1781. Brevemente critica las malas traducciones, entre los vicios de la cultura superficial.

70 Álvarez JunCo, op. cit. p. 103. Así lo interpretaba A. Filonoo, Desengaño de malos traductores, Madrid 1786, p. 9: En la biblioteca de su república de las letras «No hallan lugar, sino aquellas

Hispania, LXIII/1, núm. 213 (2003) 161-198 
Era fácil acotar lo que fomentaba el desorden social, identificado con cualquier crítica al gobierno; bien o mal, la censura había creado también un variopinto catálogo de casos estéticos por los que se podía o debía denegar la licencia de impresión; ahora quedaba por determinar si valía la pena fatigar las prensas con papeles que no aportaran nada al progreso de los conocimientos: eso era lo que los censores consideraban inútil. ¿Y lo útil? No siempre orientado hacia un fin material, sino, en el caso del Extracto de la muerte de Mr. Voltaire, Barcelona 1793, «Lo útil que sería su reimpresión para azer ver a sus apasionados la desgraciada muerte que tubo" ${ }^{71}$. Útil en lo religioso, pero nada indicada para apaciguar ánimos en plena Revolución. Desde luego no era útil ese libelo, si se trataba de fortificar la fe del rebaño. Y si no se conseguía, no se debía imprimir nada en materia - por ejemplo la Historia Chronológica Sagrada escrita por el predicador general de los franciscanos González Zaldívar y con censura de la comunidad de San Martín, «que en vez de servir de edificación de los Fieles no pueden producir otro efecto que desacreditar la religión o dar motivo para que los incrédulos de nuestros días la desacrediten», firmada por Fr. R. De Arrieta $^{72}$ - En este primer sentido, el criterio de útil en lo social se mezcla con la religión para formar un aspecto extraordinariamente viscoso, porque lo útil o inútil de ello se medía del modo más arbitrario.

Afirmo que tiene el sermón poca utilidad para los Christianos: que se ostenta en él más la agudeza en persuadir su asunto, que el provecho espiritual que se debe procurar siempre en la cátedra del Espíritu Santo ${ }^{73}$.

El parecer definitivo del expediente del Sermón apologético predicado por Fr. Joseph Martín, O.S.F. en San Felipe el Real había pasado por varias censuras y contracensuras favorables o contrarias según la orden de observancia del censor encargado. Por eso el Juez de Imprentas remataba su informe en 27/IV/1778: «Digo que no es conveniente se dé.lugar a que las congregaciones y comunidades de esta Corte tomen empeño, ni calor, con el qual se ofendan mutuamente con apologías, sátyras o libelos». Entonces el concepto de útil para el público se

obras que son conocidamente útiles a la República, enseñando a los hombres algunas verdades, y dirigiéndolos en el cumplimiento de sus respectivas obligaciones».

71 Según la petición del librero de Madrid Manuel Quiroga, rechazada en 18/VI/1793, AHN Cons leg 11280/24.

72 25/V/1779, Impresiones 5542/23.

73 Impresiones 5536/42; también A. Muñoz y Torres, Discurso astronómico... con censura de Juan de Aravaca: «no se debe publicar porque es enteramente inútil, pues lo poco que en ella se pudiera tolerar se halla mejor escrito en otros Libros muy comunes». No ha lugar 22/IV/1760, Impresiones 50638; o la censura Isidoro Rubio, maestro en el convento de San Martín: «Los libros deben tener además de la pureza de la fe y buenas Costumbres alguna utilidad pública o edificación del próximo [...] Este libro de La fe triunfante sólo puede ser útil a los maliciosos que quieran tener un patrón eterno de las familias penitenciadas». No ha lugar 5/XII/1756. También J. Herramelluri, El gran Piscator de la Rioxa... Impresiones 50631. 
mezclaba con el de útil (interés) para el gobierno por evitar polémicas y turbaciones del orden social. "No reynando en este país los errores que pretende convatir el autor, parece inoportuna la obra». Es la censura de la Real Academia de la Historia y el consiguiente «escúsese» a Vila y Campos, De la sacra y augusta dignidad de los monarcas ${ }^{74}$.

Por otra parte, el escurridizo concepto de lo útil sub specie religionis rozaba la moralidad pública con la consiguiente vigilancia de las obras menos adecuadas para alimentarla. Entre ellas, a los ojos del vicario general de Madrid, el Viage del sentimiento, de Sterne, en 1799; para el religioso, se trataba sencillamente de algo «mui inútil», de un "Conjunto de vagatelas inconexas» 75 . El mismo fino crítico literario tuvo que censurar también en el mismo año el Discurso sobre la educación de las mugeres, de Tomás de la Torre, pero en este caso su criterio estético dejaba paso a consideraciones más prácticas, y se declaraba contrario a la impresión de esa obra porque las mujeres no necesitaban ninguna educación, y por el contrario, de recibir conocimientos de filosofía, letras u otras materias se volverían marimachos. Está claro que se rechazaba la licencia en vistas al interés de la sociedad para preservarla de pretensiones inútiles ${ }^{76}$.

En el campo específico de la literatura y de las obras pedagógicas y/o científica es donde la paradoja ilustrada se muestra con toda su crudeza, al tener que combinar el interés de la utilidad social con lo que se reputaba superfluo: a G.M. Caro y Rejudo no se le concedió licencia de reimprimir su Explicación del libro $4^{\circ}$ y $5^{\circ}$ del arte de gramática de Antonio Nebrija en 1 de agosto de 1770: que publicara, decía el Consejo, algo "que sea más útil y conveniente al público» ${ }^{77}$. Ahora bien esa paradoja ilustrada no es privativa de la política española, pues en un país de típico despotismo ilustrado como era Austria la acción del gobierno «de Marie-Thérèse visait à maintenir, d'une part, les sujets dans l'ignorance pour mieux les faire accepter leur situation sociale, et de l'autre part voulait empècher le mauvais gout et la vulgarité culturelle qui étaient les fruits de l'ignorance de la population ${ }^{78}$. El rey-déspota era siempre censor en cualquier país. Lo que no se nota demasiado en España es lo que Savater llama la «paradoja de la época»: se exigía libertad de imprenta para ciertas obras que la defendían y la prohibición de otras que atacaban a las primeras ${ }^{79}$.

74 4/XII/1790 Impresiones 50676.

75 Impresiones 5563/31. Es la traducción del Sentimental Journey, importante hito de la literatura prerromántica europea.

76 Impresiones 5563/32. «Dígase a este Ympresor que ocupe sus prensas en obras más útiles al público», 22/IX/1779, G. Falconi, Obras espirituales, Impresiones 50672; 29/VII/1773, J.B. De Murcia, Sermones, Impresiones 50667.

77. Impresiones 50664. Las mismas razones del rechazo para J. Boneta, Gritos del purgatorio, reimpresión de 1768, Impresiones 50662, y para F.A. Escartín, Kalendario manual y estado eclesiástico de España, 1782, con censura de la Cámara: haría más daño que bien. 9/XII/1782, AHN Cons leg 11276/29.

78 De aquí la consiguiente ambigüedad. LAVANDIER, J.P.: Le livre au temps de Marie-Thérèse 1740-1780, Berna 1993, pp. 46 y ss; ID. Le livre au temps de Joseph II et de Léopold II, Berna 1995.

79 SAVATER, «Censura.... cit. pp. 28-29. 
El parecer de los fiscales del Consejo era muy claro en algunos casos, como el de la obra de Renuncio, la Instructio predicatorum:

Basta la simple lección del tal librito para conocer que es de aquellos inútiles y sin provecho [...] Y a la verdad en unos tiempos en que S.M. y el Consejo de desvelan por el adelantamiento de los estudios y por la ilustración pública sería de pernicioso exemplo y de malas consequencias dexar correr una obra que no puede instruir a nadie, radicalmente; que puede torcerle hasta las primeras nociones, y que no haría bonor alguno a las producciones Nacionales [...] El Autor no sólo está disculpado con su buena fe, y con aver procedido sobre el gusto que ha reinado en otros tiempos en que sería educado.

Los libros sin provecho estaban prohibidos en la Nueva Recopilación, I, VII, 23 e II, IV, 48. Interesantísimo el caso de un cierto J. Pérez y su obra Compendio Histórico, que el fiscal del Consejo J. A. Pita había denunciado en cuanto que "podría traher algunos incombenientes». El Juez de Imprentas Felipe Rivero informaba que el libro lo había censurado el abad de Montserrat pocos meses antes. Y entonces el mismo Juez de Imprentas se dejaba llevar por sus consideraciones profesionales: «Si bien me sonó a escrito insulso y de ningún fruto y de aquellos a cuia publicación favorecen poco las Leyes del Reyno especialmente la 48 del lib. $2^{\circ}$ tit. $4^{\circ}$ de nuestra Recopilación y otras, es cierto también que esta Santa Ley ha perdido en la práctica mucho de su vigor, y que a observarse por su letra, apenas tendría exercicio mi Subdelegación porque es tan poco lo bueno que viene que o se ha de cerrar la puerta o nos hemos de contentar con obras de bondad negativa a la abentura de que la benignidad de esta indulgencia excite a escribir a muchos, y entre tantos salga alguno que nos desagravie, nos honrre y nos ilustre». Parece que el Juez de Imprentas no caía en la cuenta de que tal vez fuese la censura la que producía tanta mediocridad, y continuaba: «El punto de la libertad o restricción de Imprentas en cosas indiferentes a la Religión, Regalías y buenas costumbres tiene partidarios que son, como todos los de nuestros días, fogosos. Unos quisieran que estubiesen en esto muy floxas las riendas, o que no las hubiera, y otros desaprueban que haya en esto laxitud. Yo conozco la dificultad y los escollos de ambos extremos y sólo sé decir que la quistión no está decidida, ni se decide por reglas generales o remisión al arbitrio y prudencia del Juez pudiendo salirse de este Cahos si se trabajase de propósito por buenas manos en busca de este equilibrio difícil para lo qual contribuirían sino me engaño los dictámenes que dieron el año de 1770 los Literatos de más nombre que tenía entonces la Nación por encargo del Consejo donde existe este Expediente erudito que yo he leído letra por letra, y que bien disfrutado puede quando no deslindar perfectamente la cosa a lo menos sacarla de la obscuridad y generalidades en que está» ${ }^{80}$. Además ya había obras excelentes en España, como la Rethorica Ecclesiastica de Fray Luis de Granada. Este caso revela la contradicción entre la voluntad innovadora y la inercia

so 24/XII/1789, Impresiones 5555/31 y 5533, I/72.

Hispania, LXIII/1, núm. 213 (2003) 161-198 
de la tradición, que aquí se manifestaba en disposiciones normativas, que cae de lleno en lo que se ha definido como la paradoja de la Ilustración ${ }^{81}$.

Lo verdaderamente complicado no es, llegando a este punto, establecer lo que el magistrado podía encontrar útil o inútil, sino ver qué podían tener en común, para que se los clasificara en la misma categoría, un tratado de gramática, una obra de devoción y un manual para religiosos. Tal vez pueda encontrarse una pista siguiendo las decisiones del Consejo en cuanto a la impresión de romances. A primera vista sería difícil encontrar un género literario más genuinamente nacional, pero los Romances Históricos que se querían reeditar en Valencia en 1772 encontraban un tajante

No ha lugar, y dése orden al Regente de Valencia para que no permita se impriman semejantes papeles, ni que se vendan y que se baga saber a este y a los demás Ympresores que se ocupan en esto se dediquen a imprimir otras obras útiles ${ }^{82}$.

Desde luego que estos textos se podrían autorizar, «considerando que principalmente se dirigen a ocupar a la gente sencilla algunos ratos que suele emplear en otras lecturas perjudiciales» según consideraban los censores ante algunos títulos, sobre todo cuando, como ha señalado Lopez, la falta de autores favorecía la reedición de obras del siglo anterior, y entre ellas de romances. Para los censores esa moda era grave entre otras consideraciones porque los romances eran una invitación a entrar en el temido mundo de lo «novelesco» ${ }^{83}$. Los romances no eran materia de la que el Consejo opinara demasiado bien, y así se rechazó la licencia de reedición para Ginés Pérez de Hita, Historia de los bandos de los cavalleros Moros de Granada y la de los Catorce Romances a la Passión de $\mathrm{Nr}^{\rho}$ Sr. Jesu-Christo di Lope de Vega, en este caso, lo que es más escalofriante, porque se llamaba romances. El hecho de que el mero título fuera criterio de aprobación de la obra da mucha luz sobre el calado intelectual de la censura, y de su coherencia hablan los pareceres encontrados ante textos semejantes. Así, ante el Teatro de Marte Español, de Muñoz, la R.A.H. declaraba que

81 El nombre del gran escritor es central aquí para entender lo que se ocultaba bajo la capa del estilo. Mayans invitaba a los escritores españoles a que abandonaran «el desenfreno barroco» y volvieran a los "príncipes de la elocuencia española» de Fray Luis de León Y Fray Luis de Granada, LOPEZ, F. Historia de la Literatura Española en el siglo XVIII, II, edición de G. Carnero, p. 598. Álvarez Junco hace notar que, precisamente para fundar la literatura nacional según los paradigmas ilustrados se pedía a los escritores que dejaran de lado justamente el estilo más notable de las letras españolas. ÁlVAREZ JUNCO, op. cit. nota 52 p. 289.

8213 de noviembre de 1772 Impresiones 50666, o las Quarenta historias assí sagradas como profanas, Impresiones 50667, 5/111/1773. Las citas siguientes son: Historia de los bandos... Impresiones 50666, Romances... publicados en Burgos sin fecha, Impresiones 50664, con decisión directa del Consejo $11 / \mathrm{V} / 1770$.

83 LOPEZ, F. «Las malas lecturas», Bulletin Hispanique, 100, 2, 1998. 
No se ba ballado motivo que se oponga a la licencia que pretende, y traen [los once romances] la utilidad que el Pueblo los lea en lugar de los que no contienen sino milagros apócriphos e historietas ridículas y de mal exemplo ${ }^{84}$.

Aquí la Academia volvía a valorar la utilidad de que el pueblo leyera algo que no fuera de mal ejemplo a pesar de tratarse de romances, pero el Consejo decidió no autorizar esa obra; sin embargo, no es fácil comprender qué podían tener los romances que no conviniera al pueblo, ni lo declaraba el Consejo. Ciertamente no se los podía acusar de atentar contra la fe, ni tampoco de que tuvieran «aquella desdichada utilidad de la diversión por la que se le permite a los ingenios embobar y entretener al Vulgo» como era el caso de F. Álvarez, O.S.B, y su Lustros... ${ }^{85}$. No parece probable que los magistrados pensaran que fueran «Sátira, y cuchufleta en beneficio sólo de ociossas personas para socorro de sus urgencias, y pasatiempo de necios» ${ }^{86}$. Parece que, para los ilustrados, la diversión fuera el enemigo número uno. Se juntan en la misma condena los aspectos gratificantes de la literatura de evasión, sus efectos inmorales, su inutilidad en suma en el nuevo concepto de lo «novelesco». «Fantasía y el ensueño, de allí el desacato de cualquier autoridad y hasta el olvido de Dios» como se quejaban los moralistas. Era el género lo que se criticaba, por inútil (p. (pp. 476-477). Y al llegar a 1799 «se prohiben de un plumazo las novelas»; «En suma se considera que cuanto llega de allende los Pirineos no es solamente deshonesto sino políticamente subversivo» ${ }^{87}$.

Se puede llegar a comprender, que no a justificar, que no se admitiera la publicación de colecciones de cuentos de casos raros como la de Colmenero, Instrucciones doctrinales... No se podían imprimir porque el Consejo no quería ${ }^{88}$.

${ }_{84} 28 / \mathrm{X} / 1769$, denegada la licencia Impresiones 5531/21.

85 Lustros de Álvarez proseguidos. María Santísima buelta se su destierro de Egipto Triunfante y Vencedora. Impresiones 50656, según la censura de Diego de Torres Villarroel, 22/X/1742.

86 F.Garau S.I, La fe triunfante, según censura di Antonio Téllez de Acevedo. Denegada licencia 14/III/1735, Impresiones 50685. E.A. Del Riego quería editar sus Fábulas morales e expensas de la Imprenta Real porque no tenía dinero; se presenta a la censura de la Sociedad Económica de Oviedo. Dictamen de Joseph Antonio Fita, quien puntualiza que debería haber presentado el original «para graduar su mérito». En cualquier caso, como ya había obras de semejante asunto y de gran éxito de público, no merecía la pena siquiera censurar; 11/II/1793 AHN Cons leg 11280/39. También el caso de J. De Santos Capuano, «El Ciego junto a San Marcos» y sus Tertulias indicativas. La primera Tertulia ya se había autorizado; ahora quería imprimir la segunda y la tercera. Como era ciego, fue su mujer quien firmó la petición, y fue su censor J. A. Fita: «Puede tener alguna utilidad el que circulen por la Nación semejantes Papeles para fomentar el justo odio que generalmente se tiene a las máximas detestables de los Franceses de este tiempo en correspondencia con lo que ellos han procurado esparcir por la misma y por toda Europa», mas a pesar de las buenas intenciones de su autor el producto era pésimo, por lo que se decreta el temido no ba lugar en 29/IV/1793, AHN Cons leg 11280/38.

87 LOPEZ: «Las malas lecturas», cit. pp. 276-277. Los temas de los «novelesco» eran las aventuras heroicas y, sobre todo, y ahí estaba el peligro, las amorosas.

88 15/XI/1772 Impresiones 5529/6.

Hispania, LXIII/1, núm. 213 (2003) 161-198 
Pero por mucho que se intente deslindar el criterio último del censor, no se alcanza nunca una plantilla única de normas aplicables. La conclusión es que si hubo una decisión evidente de vigilar la imprenta en el siglo XVIII, esa voluntad demostró su coherencia sólo en el establecimiento de los mecanismos legales de la censura; en cambio, el Poder no se preocupó en ningún caso por ofrecer a sus magistrados indicaciones básicas sobre su acción, más allá de las afirmaciones genéricas a propósito de la defensa de la fe, las regalías y las buenas costumbres, y de hecho la autonomía de juicio de los censores salta a la vista. El criterio unificador de tantas opiniones individuales lo ponía entonces el Consejo con sus decisiones, casi siempre restrictivas. Claro que espigando entre las justificaciones de las sentencias se puede esbozar una colección de declaraciones de principios de acción del Consejo de Castilla; pero la ambigüedad y la contradictoriedad de muchas de ellas sólo permiten una reconstrucción de los principios implícitos en los criterios de censura (aunque es muy probable que ninguna censura pueda justificarse con un sistema coherente de reglas más allá de lo genéricamente referible a la voluntad del Poder). Algunas instituciones como la Real Academia de la Historia, o la Española, al ser emanaciones directas del Consejo, se pueden tomar por otras tantas manifestaciones de la opinión del Poder; no así las de conventos o colegios religiosos, que mantenían un grado de libertad de criterio, y que a menudo dictaban censuras favorables de obras que después el Consejo rechazaba, en lo que era el enfrentamiento soterrado entre poder civil y eclesiástico, nunca del todo abandonado en el siglo Dieciocho. Cuando el carmelita J.G. De La Purificación presentaba su Ética o filosofía moral en 1786, la censura de los catedráticos de lógica y filosofía moral de los Estudios de San Isidro era favorable, «por lo que nos parece que puede V.A. permitir su impresión». Pero la Sala de Gobierno insistía: «Dígase a estos Censores que especifiquen si esta obra será útil y conveniente para la enseñanza pública» y entonces la respuesta era «No, señor», porque en la obra las verdades naturales se confundían con las reveladas ${ }^{89}$. Parece muy difícil aceptar que unos teólogos, sabiendo de ese error, hubieran presentado la obra bajo una luz tan favorable; el caso es que el Consejo no se fiaba de sus censores y de este episodio podría hipotizarse que su objetivo principal era la utilidad en cuanto buena pedagogía, entendida como enseñanza para mejorar el nivel moral del pueblo. Lo decía la Academia Española a propósito del Testamento del philósopho Marcelo de Estrada:

Este papel es una crítica entre seria y burlesca de varios asuntos morales, filosóficos, de medicina varia que no contienen enseñanza ni instrucción que pueda ser útil al público [...] es más capaz de dar materia en alguna de sus partes a un saynete de comedia que a la seria reforma de las costumbres ${ }^{90}$.

89 Impresiones leg 5552/97.

90 14/I/1774 Impresiones 5535/8. Testamento Político del Filósofo Marcelo, «obra que verosímilmente hemos de considerar como suya» esto es de Rubín de Celis p. 118, URZAINQUI MIQUÉLEZ, I.: «Francia y lo francés en la prensa crítica española a finales del reinado de Carlos III: el "Censor" y su 
En estas palabras hay un fondo que sí puede dar una pista sobre la visión de la cultura que tenían los ilustrados, al menos en cuanto se refería a esa parte de la producción editorial que se podía ofrecer al público: la seriedad. Nada de sainetes, nada de humorismos trasnochados, sino un tono que se aviniera con la tradicional gravedad de lo español. Muy lejos estaban estos ministros del esprit de finesse de sus mentores de más allá de los Pirineos, pero a veces remitirse a Francia era una búsqueda de principio de autoridad para rechazar una obra, como en el caso de la edición de las novelas de Mr. de La Calprenède:

Desde que más de siglo y medio ha, comenzó el inagotable Mr. De La Calprenede a fastidiar al mundo con sus escritos, todos ellos, y principalmente sus tres Novelas, Cleopatra, Casandra y Faramundo fueron objeto de la mofa de la misma Francia: boi, sin embargo de que su abundancia ba dado materiales a muchos para aprobecharse' de ellos mejorándolos, sólo su nombre vasta en toda Europa para decir muchas bufonadas

decía el Vicario General de Madrid metido a crítico literario ${ }^{91}$. Pero también Cabarrús, en su faceta de censor, encontraba la misma mancha en los Pactos, convenciones... de Vicente del Seixo en 1788; sólo que además, en cuanto hombre político, teorizaba la necesidad de respetar las leyes vigentes, dando una interpretación de su razón última de ser: parece desprenderse de sus palabras que las medidas de censura estaban dirigidas a impedir que los autores hicieran el ridículo y que, de rechazo, el mismo ridículo tocara al gobierno que lo toleraba...

Esta obra, que sólo sería inútil y ridícula, donde la libertad de la Imprenta deja las obras a la suerte que las prepara la opinión pública, por el juicio que bace de su mérito, me parece perjudicial donde las leyes preocupan en algún modo esta opinión por la especie de aprobación que supone el permiso de imprimirlas y publicarlas ${ }^{92}$.

Luego pudo haber entre los integrantes de la censura gubernativa un elemento no declarado pero que aflora latente en muchas opiniones y que consistiría en conservar el tradicional, adusto espíritu castellano pero no como fin en sí mismo sino para mantener el prestigio nacional. Las pruebas se rastrean entre líneas en muchas sentencias: «en nuestra España no hai necesidad alguna de ella, por los muchos y excelentes Libros ascéticos, que tenemos» decían los censores de las Consideraciones y discursos de Cesare Calino, con un tono despectivo evidente:

La obra es en lo substancial mui buena y que sin duda será mui útil en la Italia para el uso de los Curas, y demás para quienes la escrivióo ${ }^{93}$.

\footnotetext{
"corresponsal"", La imagen de Francia en España en la segunda mitad del siglo XVIII, Alicante-París 1996, según la edición de F. Sánchez Blanco, Oviedo 1991. En este caso el texto se habría presentado a la censura bajo nombre supuesto, lo que ya de por sí infringía las normas vigentes.

$91 \quad 5 / 1 / 1798$ Impresiones 5562/9.

92 18/IV/1789 Impresiones 5554/106.

93 26/VIII/1776, Censura del capítulo de San Isidro, Impresiones 5538/72.
}

Hispania, LXIII/1, núm. 213 (2003) 161-198 
Todos los datos hasta aquí recogidos ofrecen el panorama de una realidad difusa. A los censores designados se les encargaba una tarea y para llevarla a término tenían a su disposición un marco legal que, sin embargo, era ineficaz para guiar concretamente su acción, porque falto de criterios de valoración. Luego en realidad el peso de las decisiones censorias se dejaba completamente en manos de los mismos censores. Ésta es la única posible explicación plausible para la abigarrada casuística que se desprende del análisis de las fuentes. Y de estas consideraciones se origina también la duda de si está fundada cualquier pregunta acerca de la eficacia del filtro censorio. A cada instante es dado observar que obras con los mismos vicios y defectos que habían ocasionado la denegación de licencia de algunos textos la recibían de otro censor, y que escritos de materias que unos opinaban eran superfluas o impertinentes recibían luz verde para su publicación por parte de otros. Entonces la única conclusión posible es que el sólo resultado de la censura previa gubernativa fue el de crear un sentimiento de sociedad vigilada entre las capas pensantes, de mutilación intelectual fundada más en la reserva y prudencia de los autores que en la eficacia concreta de los criterios de valoración de sus obras. 